Article

\title{
Feasibility Study of Plasma-Catalytic Ammonia Synthesis for Energy Storage Applications
}

\author{
Kevin H. R. Rouwenhorst *(i) and Leon Lefferts *(D) \\ Catalytic Processes \& Materials, MESA+ Institute for Nanotechnology, University of Twente, P.O. Box 217, \\ 7500 AE Enschede, The Netherlands \\ * Correspondence: k.h.r.rouwenhorst@utwente.nl (K.H.R.R.); 1.lefferts@utwente.nl (L.L.)
}

Received: 10 August 2020; Accepted: 25 August 2020; Published: 1 September 2020

check for updates

\begin{abstract}
Plasma catalysis has recently gained traction as an alternative to ammonia synthesis. The current research is mostly fundamental and little attention has been given to the technical and economic feasibility of plasma-catalytic ammonia synthesis. In this study, the feasibility of plasma-catalytic ammonia is assessed for small-scale ammonia synthesis. A brief summary of the state of the art of plasma catalysis is provided as well as a targets and potential avenues for improvement in the conversion to ammonia, ammonia separation and a higher energy efficiency. A best-case scenario is provided for plasma-catalytic ammonia synthesis and this is compared to the Haber-Bosch ammonia process operated with a synthesis loop. An ammonia outlet concentration of at least $1.0 \mathrm{~mol}$ \% is required to limit the recycle size and to allow for efficient product separation. From the analysis, it follows that plasma-catalytic ammonia synthesis cannot compete with the conventional process even in the best-case scenario. Plasma catalysis potentially has a fast response to intermittent renewable electricity, although low pressure absorbent-enhanced Haber-Bosch processes are also expected to have fast responses to load variations. Low-temperature thermochemical ammonia synthesis is expected to be a more feasible alternative to intermittent decentralized ammonia synthesis than plasma-catalytic ammonia synthesis due to its superior energy efficiency.
\end{abstract}

Keywords: plasma catalysis; ammonia; process design; electrification; scale-down

\section{Introduction}

Renewable wind energy and solar power increasingly penetrate the electrical power grid, spurring the electrification of the energy landscape [1]. However, as these energy sources are intermittent, energy storage is required. A wide range of technology is available, including batteries and thermo-mechanical storage for short-term energy storage, typically up to a few days [2]. Chemical energy storage and pumped hydropower are the main alternatives for seasonal energy storage [2-4]. Even though pumped hydropower is a potential solution for low-cost energy storage in naturally suited areas [4], the energy density of such systems is low, and pumped hydropower heavily depends on the availability of large natural water formations.

Chemical energy storage in the form of hydrogen or hydrogen carriers has been proposed to solve the intermittency challenge. Renewable hydrogen is produced from water via electrolysis using renewable electricity, producing oxygen as a by-product. Hydrogen can be combusted to water in a fuel cell or in a gas turbine, producing electricity again. However, hydrogen is not easily stored on the long-term. Therefore, hydrogen carriers are required and ammonia $\left(\mathrm{NH}_{3}\right)$ is one of the options $[3,5]$. Ammonia is currently mainly produced for fertilizer applications [6-8]. However, ammonia may be a hydrogen carrier in the circular economy $[5,9,10]$. In this case, intermittent renewables such as solar, tidal and wind power are coupled with chemical plants to produce ammonia. 
Currently, ammonia is mainly produced with the Haber-Bosch process, continuously operated at high temperature and pressure, i.e., $400-500{ }^{\circ} \mathrm{C}$ and $100-300$ bar $[6-8,11]$. The high temperature is required to activate the stable $\mathrm{N} \equiv \mathrm{N}$ triple bond over the industrial catalyst, and a high pressure is required to shift the equilibrium to ammonia. Typically, Haber-Bosch plants have high production capacities of up to $3300 \mathrm{t}-\mathrm{NH}_{3} \mathrm{~d}^{-1}$, with a potential increase to $5000-6000 \mathrm{t}-\mathrm{NH}_{3} \mathrm{~d}^{-1}$ in the near future [12,13]. This corresponds to a few gigawatt (GW) in the case of an electricity-driven Haber-Bosch plant. Such electrolysis-based Haber-Bosch plants operate at an energy cost of about $26-40 \mathrm{GJ} t-\mathrm{NH}_{3}{ }^{-1}$, depending on the electrolysis technology used [14]. About 95\% of this energy is required for the hydrogen production and the remaining part is required for nitrogen purification and ammonia synthesis. The theoretical minimum energy input for ammonia synthesis from air and water is $21.3 \mathrm{GJ}$ t- $\mathrm{NH}_{3}{ }^{-1}$ [7].

Upon scaling down the Haber-Bosch process, the energy losses increase and the energy consumption for ammonia synthesis increases (see Figure 1). Down to the 1-10 microwave (MW) scale (equivalent to 3-30 $\mathrm{t}-\mathrm{NH}_{3} \mathrm{~d}^{-1}$ ), energy losses are limited and the energy consumption for ammonia synthesis is about $36-40 \mathrm{GJ}$ t- $\mathrm{NH}_{3}{ }^{-1}$ [15]. However, upon further scaling down, energy losses become increasingly severe, and using alternative technologies becomes attractive. Non-conventional technologies typically cannot compete with Haber-Bosch at large-scale, due to the high energy efficiency of Haber-Bosch. However, alternative technologies operating under milder conditions can be beneficial for small-scale production. This is important for intermittent operation required in the case of rapid variation in the availability of solar and wind power. Small-scale ammonia synthesis may be relevant for energy storage, specifically for isolated small communities.

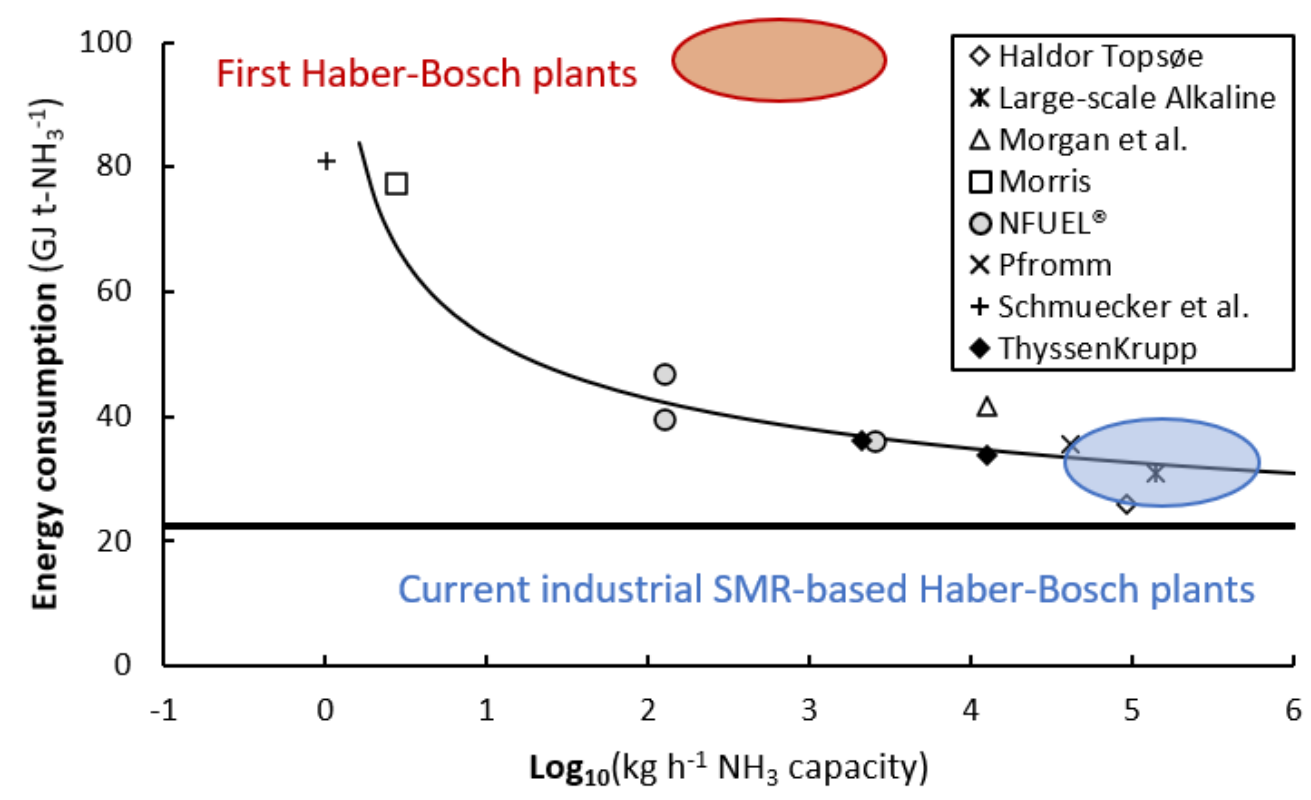

Figure 1. Energy consumption of electrolysis-based Haber-Bosch processes as function of ammonia production capacity. Adapted and modified from [16]. Original references [17-26]. One microwave (MW) corresponds to approximately $100 \mathrm{~kg} \mathrm{~h}^{-1}$ ammonia.

\subsection{State of the Art of Plasma-Catalytic Ammonia Synthesis}

Plasma catalysis has recently gained attention for electrification of chemical processes and for energy storage applications [27-31], and for ammonia synthesis in specific [32-34]. Plasma is the fourth state of matter, in which electrons, ions, molecules, radicals, and excited species exist in a quasi-neutral state. In case of thermal plasmas, electrons and heavier species have the same temperature. On the other hand, non-thermal plasmas, the electron temperature is significantly higher than that of heavier ions and neutral species. Non-thermal plasmas can be coupled with a catalyst. Excited species generated in the plasma (for instance, vibrationally activated nitrogen, $\mathrm{N}_{2}(\mathrm{v})$ ) can have an enhanced 
adsorption rate as compared to ground-state molecules. As $\mathrm{N}_{2}$ dissociation is usually the bottleneck for ammonia synthesis, plasma activation of $\mathrm{N}_{2}$ may generate a synergistic effect with the catalyst.

Plasma catalysis potentially has a fast response to intermittent renewable electricity, although low pressure absorbent-enhanced Haber-Bosch processes are also expected to have fast responses to load variations. In the upcoming section, the state of the art of the electrolysis-based Haber-Bosch process and an alternative plasma-catalytic process are discussed. This serves as a starting point for process evaluation of plasma-catalytic ammonia synthesis.

An overview of reported energy consumptions for ammonia synthesis in various types of plasma reactors is shown in Figure 2. Among the plasma reactors, dielectric barrier discharge (DBD) reactors have been studied most extensively since the 2000s [32,33,35]. Microwave (MW) and radiofrequency (RF) plasmas have been studied in the 1980s-1990s, although recently a few articles have been published on this subject as well [33]. Glow discharges, inspired by the commercial Birkeland-Eyde process for $\mathrm{NO}_{\mathrm{X}}$ production in the early 20th century, have been studied in the 1920s-1990s [32,33]. Other technologies, such as arc discharges and plasma jets have only been reported in a few studies, mostly with an exploratory character $[33,36]$. Various authors have discussed plasma reactors extensively $[27,32,37]$.

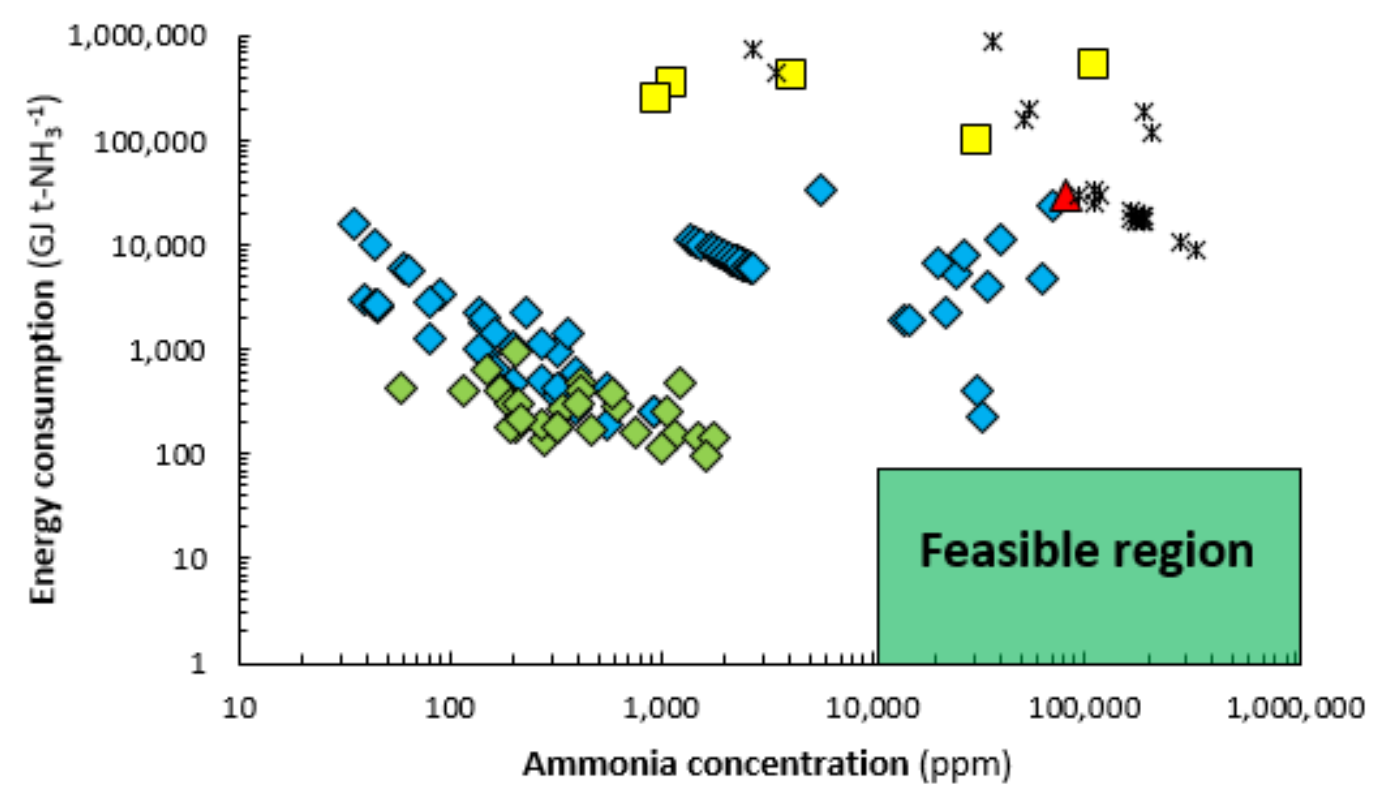

Figure 2. Reported energy yield vs. ammonia concentration at various process conditions. Constructed and extended from [38]. Original references: dielectric barrier discharge (DBD) (alternating current, AC) $\diamond$ [39-52], DBD (pulse) $\diamond$ [43,53], glow discharge $\Delta$ [54], MW $\square$ [55-59] and radiofrequency (RF) * [60-65]. Note that the feed composition varies among the references, and therefore the ammonia yield. In case of a stoichiometric feed ratio, the ammonia outlet concentration is equal to the yield (at $0.0 \mathrm{~mol}$. \% $\mathrm{NH}_{3}$ inlet). The feasible region is discussed in Section 1.2.1.

\subsection{Comparison of the Small-Scale Haber-Bosch Processes and State-of-the-Art Plasma Catalysis}

Figure 3 shows a comparison of reported state-of-the-art data on energy consumption of the electrolysis-based Haber-Bosch process, both at the $10 \mathrm{~kW}$ and $10 \mathrm{MW}$ scale, as well as plasma-catalytic ammonia synthesis. Electrolysis-based hydrogen production is required for both the Haber-Bosch process and plasma catalysis at an energy consumption of about $31.4 \mathrm{GJ} \mathrm{t}-\mathrm{NH}_{3}{ }^{-1}[16,66]$. Nitrogen is purified for all alternatives via pressure swing adsorption at an energy consumption of about $1.0 \mathrm{GJ}$ $\mathrm{t}-\mathrm{NH}_{3}$ [16]. At the $10 \mathrm{MW}$ scale, the high pressure ammonia synthesis loop of the Haber-Bosch process has a limited energy loss and consumes about 3.6 GJ t- $\mathrm{NH}^{-1}$ [67]. However, at $10 \mathrm{~kW}$, the energy consumption of the high pressure ammonia synthesis loop is as high as $45-50 \mathrm{GJ} \mathrm{t}-\mathrm{NH}_{3}{ }^{-1}$ (see Figure 3). This is mainly due to large heat losses from the synthesis reactor operating at high temperatures. 


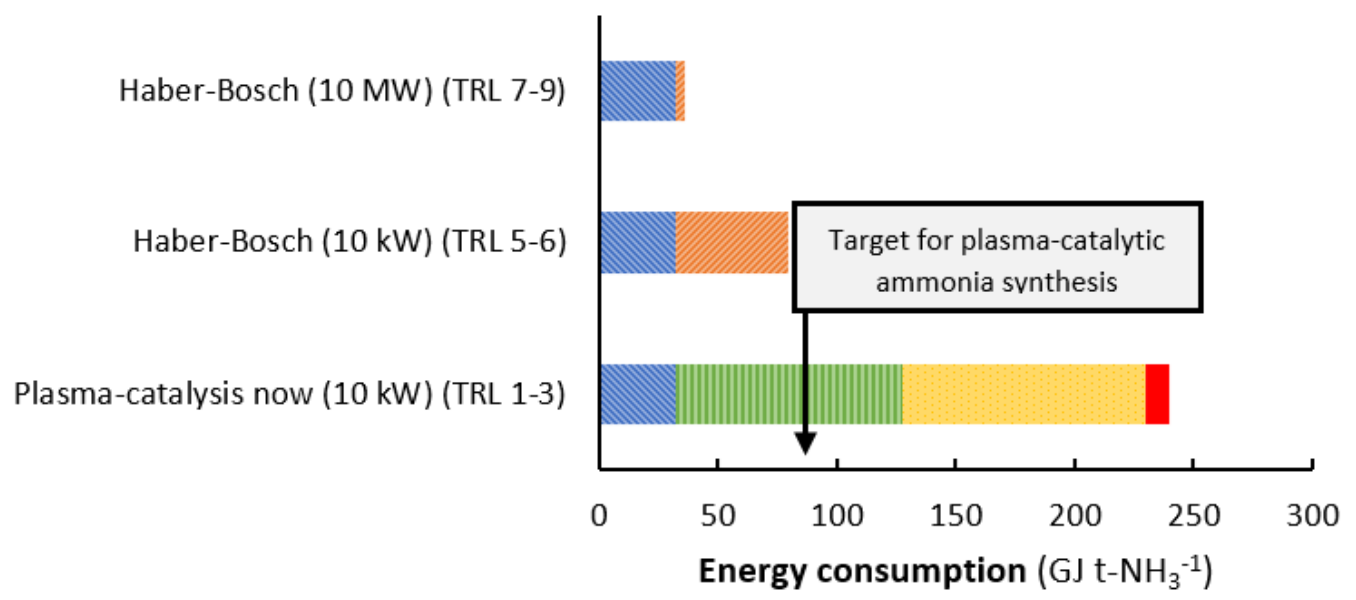

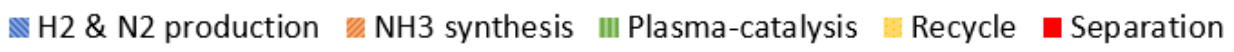

Figure 3. Estimated energy consumption of state-of-the-art, small-scale, electrolysis-based Haber-Bosch, and plasma catalysis. For the Haber-Bosch process, estimates are based on reported energy consumption in Figure 1. For plasma catalysis, the energy consumption for gas recycling and ammonia separation is based on estimates in for low pressure, low conversion systems with solid sorbents as reported in $[16,67]$. The energy consumption for plasma catalysis is based on data from Kim et al. [43] over a $\mathrm{Ru}-\mathrm{MgO} / \gamma-\mathrm{Al}_{2} \mathrm{O}_{3}$ catalyst at $0.2 \%$ conversion. The energy cost for recycling and separation with solid sorbents is discussed in Section 3.1. Technology readiness level (TRL). The TRL levels here apply for the complete system. TRL 1 is the basic idea, while TRL 9 is a commercial system. For more details, see ref. [68].

As shown in Figure 3, the state-of-the-art system for a plasma-catalytic ammonia synthesis process has a considerably higher energy consumption than the electrolysis-based Haber-Bosch process, both at $10 \mathrm{~kW}$ and at $10 \mathrm{MW}$. Plasma catalysis allows for operation at milder conditions than conventional catalysis over the industrial iron catalyst. However, plasma catalysis is only beneficial when the energy consumption of a plasma-catalytic ammonia synthesis process is at least equal to the energy consumption of the electrolysis-based Haber-Bosch process at $10 \mathrm{~kW}$ (about $80 \mathrm{GJ} \mathrm{t}-\mathrm{NH}_{3}{ }^{-1}$ ). The best reported value for plasma catalysis is $95 \mathrm{GJ} \mathrm{t}-\mathrm{NH}_{3}{ }^{-1}$ at $0.2 \mathrm{~mol} . \% \mathrm{NH}_{3}$ [43], while most reported values vary in the range between $10^{3}$ and $10^{6} \mathrm{GJ} \mathrm{t-NH_{3 }}{ }^{-1}$ at various conversion levels (see Figure 2) [33]. Furthermore, the energy consumption of recycling of unconverted $\mathrm{N}_{2}$ and $\mathrm{H}_{2}$ for the best reported plasma-catalytic systems is high, due to the low conversion levels (see Figure 2). The recycling cost is usually not reported for plasma catalysis (like in Figure 2), but is significant in case of low conversions to ammonia, i.e., below $1.0 \mathrm{~mol}$. \% $\mathrm{NH}_{3}$ [67].

\subsubsection{Targets and Strategies for More Energy-Efficient Plasma-Catalytic Ammonia Synthesis}

It is estimated that plasma catalysis may be competitive with the Haber-Bosch at a target total energy consumption of $80 \mathrm{GJ} \mathrm{tNH}_{3}{ }^{-1}$, based on the comparison with electrolysis-based Haber-Bosch

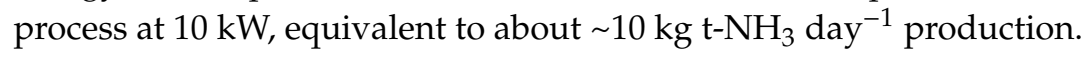

The energy costs of hydrogen production and nitrogen purification is the same for both processes and amount to about $32 \mathrm{GJ}$ t- $\mathrm{NH}_{3}{ }^{-1}$. Ammonia separation in the Haber-Bosch process is achieved by condensation. However, under mild pressure ( $<70$ bar), condensation is not feasible due to the high vapor pressure of ammonia under ambient conditions (about 7 bar) $[16,67]$. Therefore, sorbents are currently being developed for ammonia separation and storage, as discussed in Section 3.1. Typically, the energy consumption for ammonia separation with sorbents is about $10 \mathrm{GJ} t-\mathrm{NH}_{3}{ }^{-1}$, which changes little with ammonia concentration.

This implies that two functionalities primarily determine the feasibility of plasma-catalytic ammonia synthesis, namely (1) plasma catalysis, and (2) separation of $\mathrm{NH}_{3}$ and recycling of unconverted 
$\mathrm{N}_{2}$ and $\mathrm{H}_{2}$. In principle, the recycle cost is usually not an issue for industrial ammonia synthesis, as the energy cost of recycling is below $1 \mathrm{GJ} \mathrm{t}-\mathrm{NH}_{3}{ }^{-1}$ at $\mathrm{NH}_{3}$ concentrations above $1.0 \mathrm{~mol}$. \% in the reactor outlet [67]. However, for the current best-reported data for plasma catalysis, the ammonia concentration

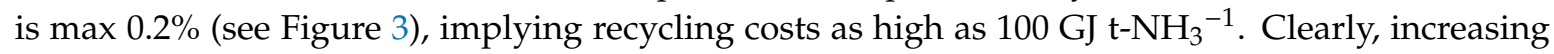
the $\mathrm{NH}_{3}$ concentration in the outlet of the plasma reactor to above $1.0 \%$, at a reasonable energy cost, is desirable. Another benefit of increasing the conversion level and consequently the ammonia concentration is the reduction in capital investment for recycling, due to the smaller compressor. In the upcoming section, potential improvements for plasma catalysis are discussed.

\section{Plasma Reactor and Catalyst Improvements to Plasma-Catalytic Ammonia Synthesis}

The plasma reactor forms the core of the plasma-catalytic ammonia synthesis process. In this section, the plasma reactor types are evaluated, as well as the necessary coupling with a catalyst.

\subsection{Plasma Reactor Type}

The first choice to make is the plasma reactor type. While dielectric barrier discharge (DBD) reactors and glow discharge reactors operate at atmospheric pressure (or elevated pressures [69]), microwave (MW) reactors and radiofrequency (RF) reactors operate at sub-atmospheric pressures. In principle, operating at atmospheric pressures is beneficial, as vacuum conditions require expensive equipment and large volumes. Furthermore, separation of ammonia is difficult at low partial pressures.

Metrics to evaluate the plasma reactor type is the energy consumption for ammonia formation (requirement about $40 \mathrm{GJ} \mathrm{t}-\mathrm{NH}_{3}{ }^{-1}$, see Figure 3), as well as the conversion (requirement $\geq 1.0 \mathrm{~mol}$. $\% \mathrm{NH}_{3}$ ). As shown in Figure 2, no data in the literature have attained this so far. It should be noted that the data shown in Figure 2 vary widely in temperature, pressure, $\mathrm{H}_{2}: \mathrm{N}_{2}$ ratio, and catalyst choice. However, the apparent general trend is that the energy consumption for ammonia formation is lowest in dielectric barrier discharge reactors. Other reactor types (glow discharges, microwave reactors, and radiofrequency reactors) have an energy consumption of one to four orders of magnitude higher. This may be attributed to the more effective plasma-catalyst coupling for a DBD reactor. Therefore, a dielectric barrier discharge reactor is the preferred plasma reactor type, with the current knowledge.

\section{Plasma Optimization}

Plasma optimization should be focused on maximizing the density of mildly activated molecular nitrogen species $\left(\mathrm{N}_{2}(\mathrm{v})\right.$ or $\left.\mathrm{N}_{2}(\mathrm{e})\right)$, rather than radical species, as the mildly activated molecular nitrogen species require less energy input than fully dissociated nitrogen radicals. Mild activation of $\mathrm{N}_{2}$ to $\mathrm{N}_{2}(\mathrm{v})$ or $\mathrm{N}_{2}$ (e) can primarily be achieved by a relatively low specific input energy (SIE). Upon increasing the SIE, the reduced electric field increases, thereby increasing the fraction of $\mathrm{N}_{2}$ dissociated in the plasma [27]. Furthermore, $\mathrm{N}_{2}$-rich feeds are beneficial for activating $\mathrm{N}_{2}$ rather than $\mathrm{H}_{2}$ [43].

Various authors have reported an improved energy efficiency upon using pulsed plasmas in a dielectric barrier discharge reactor, rather than a continuous AC plasma [43,53]. For AC plasmas, excited $\mathrm{N}_{2}$ molecules are readily dissociated due to the continuous presence of activated species. This leads to dissociation and the formation of $\mathrm{N}$ radicals, which recombine with other species and form heat. For pulsed plasmas, less of the activated $\mathrm{N}_{2}$ is dissociated in the plasma due to climbing along the vibrational ladder [70]. Thus, a pulsed plasma dielectric barrier discharge reactor is preferred as the plasma reactor.

Further modifications can be made to the plasma properties, by changing the discharge frequency and the capacitive and discharge regimes. Plasma properties can be modified by the electrode material $[45,54]$, as well as the dielectric constant in the reactor. Performance enhancement may be attained upon the physical mixture of the active catalyst with a dielectric material [40], which can be attributed to a change in electron number density and average energy distribution. 


\subsection{Reaction Mechanisms and Catalyst Optimization}

Several mechanisms towards ammonia synthesis in the presence of a plasma are being discussed, as previously reported in [38]. The various mechanisms for $\mathrm{N}_{2}$ activation are shown in Figure 4. The bond-dissociation energies of $\mathrm{N}_{2}$ and $\mathrm{H}_{2}$ are $945 \mathrm{~kJ} \mathrm{~mol}^{-1}$ and $436 \mathrm{~kJ} \mathrm{~mol}^{-1}$ respectively, which translates to $66.1 \mathrm{GJ} \mathrm{t}-\mathrm{NH}_{3}{ }^{-1}$ at $100 \%$ efficient conversion to ammonia via complete dissociation. This implies that plasma-induced dissociation and subsequent radical reactions can never be sufficiently energy efficient to attain the required $40 \mathrm{GJ} \mathrm{t}-\mathrm{NH}_{3}{ }^{-1}$ as explained in Section 1.2.1. Thus, a catalyst is required to aid in the dissociation of the molecules. As shown in Figure 4, the plasma can activate molecular $\mathrm{N}_{2}$ via vibrational or electronic excitation (denoted as $\mathrm{N}_{2}{ }^{(\mathrm{ex})}$ in Figure 4), which lowers the barrier for $\mathrm{N}_{2}$ dissociation over the catalyst. Typically, catalysts which are able to dissociate $\mathrm{N}_{2}$ are also able to dissociate $\mathrm{H}_{2}$, while some mid-late transition metal catalysts such as $\mathrm{Pd}$ and $\mathrm{Pt}$ can dissociate $\mathrm{H}_{2}$, but not $\mathrm{N}_{2}$.

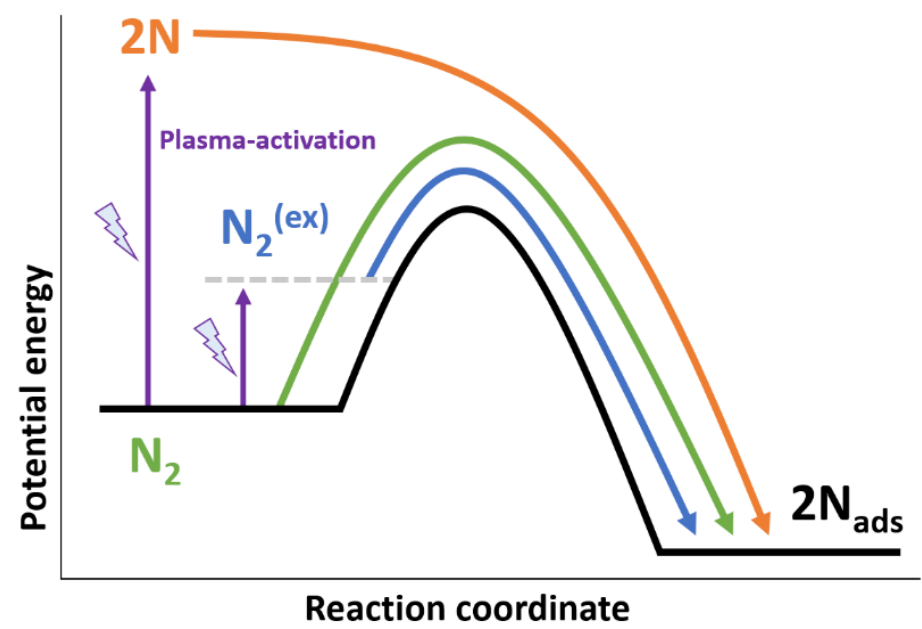

Figure 4. Various mechanisms for $\mathrm{N}_{2}$ activation by the plasma and subsequent dissociative adsorption on a metal surface. Green: thermal $\mathrm{N}_{2}$ activation on a catalyst. Blue: plasma-activated molecular $\mathrm{N}_{2}$ dissociating over the metal with a barrier over the catalyst. Orange: complete dissociation of $\mathrm{N}_{2}$ by the plasma, followed by barrierless adsorption on the metal surface.

\subsubsection{Plasma-Catalytic Ammonia Synthesis with Molecular Species}

Thus, plasma activation of $\mathrm{N}_{2}$ without complete dissociation is the required pathway for plasma-catalytic ammonia synthesis with a low energy consumption. Mehta et al. [71] proposed that plasma-activated molecular $\mathrm{N}_{2}$ can enhance the rate of ammonia formation, which was substantiated by Rouwenhorst et al. [38] for Ru-based catalysts at a low plasma power input of 83-367 J L $\mathrm{L}^{-1}$. Mehta et al. [71] postulated that the plasma activates the $\mathrm{N}_{2}$, thereby lowering the barrier for $\mathrm{N}_{2}$ dissociation, while subsequent hydrogenation steps are not influenced by the plasma.

Furthermore, Mehta et al. [71] postulated that thermally less active metals can become good catalysts for converting plasma-activated $\mathrm{N}_{2}$ to ammonia. However, the importance of plasma-activated molecular $\mathrm{N}_{2}$ (either vibrational or electronic) has been experimentally substantiated exclusively for Ru-based catalysts [38,72]. It remains an open question whether noble metals can become active for $\mathrm{N}_{2}$ dissociation after vibrational or electronic excitation. Over Ru-based catalysts, the apparent barrier for $\mathrm{N}_{2}$ dissociation over the catalyst decreases by about $40-70 \mathrm{~kJ} \mathrm{~mol}^{-1}$ upon plasma activation [38]. The discussion hereafter focuses on Ru-based catalysts, as a mechanism with excited $\mathrm{N}_{2}$ has only been proven to be possible for this metal. However, the role of the support and alkali promoters should also be valid for other metals [73].

The support has a profound effect on the ammonia synthesis activity over Ru-catalysts [74]. The ammonia synthesis rate can vary by multiple orders of magnitude, depending on the catalyst formulation. For Ru catalysts it was found that oxide supports with a low electronegativity show a 
high ammonia synthesis activity for thermal catalysis [75]. A similar trend was confirmed for plasma catalysis (see Figure 5), suggesting that a pathway via excited molecular $\mathrm{N}_{2}$ is indeed dominant. The introduction of promoters (alkali metals and alkaline earth metals) can enhance the activity further $[74,76]$. The nitrogen dissociation barrier decreases upon the introduction of an alkali metal due to electrostatic interactions [76]. A similar activity improvement upon the introduction of an alkali metal was also reported for Co catalysts [77]. For this mechanism, the temperature should be such that $\mathrm{N}_{2}$ dissociation on the catalyst and $\mathrm{NH}_{3}$ desorption from the catalyst are possible. Thus, the temperature for plasma catalysis cannot be much lower than for thermal catalysis.

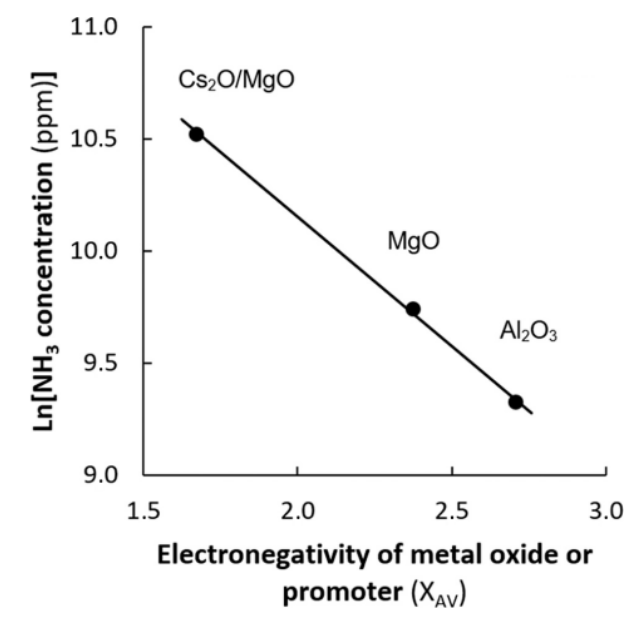

Figure 5. Ammonia synthesis rate as a function of the electronegativity for plasma-catalytic ammonia synthesis. Reproduced from [38].

The lowest reported energy requirement for plasma catalysis so far is for a promoted $\mathrm{Ru} / \mathrm{Al}_{2} \mathrm{O}_{3}$ catalyst [43]. As listed in Table 1, trends in thermal catalysis indicate that changes in the catalyst may facilitate a lower energy cost for $\mathrm{NH}_{3}$ synthesis, given that the right plasma reactor is used. Promoted $\mathrm{Ru} / \mathrm{MgO}$ catalysts are about 25 times more active than promoted $\mathrm{Ru} / \mathrm{Al}_{2} \mathrm{O}_{3}$ catalysts for thermal catalysis [78]. As similar trends are valid for plasma catalysis at low conversions (see Figure 5), an increased productivity and a lower energy cost may be attained upon using promoted $\mathrm{Ru} / \mathrm{MgO}$ catalysts. As listed in Table 1 , the enhancement for plasma catalysis upon using promoted $\mathrm{Ru} / \mathrm{MgO}$ is less profound at high conversions resulting in relatively high ammonia concentration (1.1-3.7 mol. \% $\mathrm{NH}_{3}$ ).

Table 1. Comparison of activity trends over Ru catalysts for thermal catalysis and for plasma catalysis. Thermal catalysis: data of Muhler et al. [78], $385^{\circ} \mathrm{C}, 1 \mathrm{~atm}, 40 \mathrm{~mL} \min ^{-1}, \mathrm{H}_{2}: \mathrm{N}_{2}=3: 1,138 \mathrm{mg}$ catalyst. Plasma catalysis: data of Ruan et al. [79], $180{ }^{\circ} \mathrm{C}, 60 \mathrm{~mL} \mathrm{~min}^{-1}, \mathrm{H}_{2}: \mathrm{N}_{2}=3: 1,1.1-3.7 \mathrm{~mol}$. \% $\mathrm{NH}_{3}$. Kim et al. [43], 250-300 ${ }^{\circ} \mathrm{C}, 1 \mathrm{~atm}, 1-4 \mathrm{~L} \mathrm{~min}^{-1}, \mathrm{H}_{2}: \mathrm{N}_{2}=1: 4,17.1 \mathrm{~g}$ catalyst, $0.01-0.16 \mathrm{~mol} . \% \mathrm{NH}_{3}$. Target value for plasma catalysis: $40 \mathrm{GJ} \mathrm{t}-\mathrm{NH}_{3}{ }^{-1}$ at $1.0 \% \mathrm{NH}_{3}$ at outlet. "Relative act." refers to the relative ammonia synthesis rate on various catalysts, with $\mathrm{Ru} / \mathrm{Al}_{2} \mathrm{O}_{3}$ as the base-case (1.0).

\begin{tabular}{cccccc}
\hline Catalyst & Thermal Catalysis & \multicolumn{4}{c}{ Plasma Catalysis } \\
\cline { 2 - 6 } & Muhler et al. [78] & Ruan et al. [79] & \multicolumn{2}{c}{ Kim et al. [43] } \\
\hline & Relative Act. & Relative Act. & Relative Act. & Energy Cost (GJ t-NH ${ }_{3}^{-1}$ ) \\
\hline $\begin{array}{c}\mathrm{Ru} / \mathrm{Al}_{2} \mathrm{O}_{3} \\
\mathrm{Ru} / \mathrm{Al}_{2} \mathrm{O}_{3}\end{array}$ & 1.0 & 1.0 & 1.0 & AC Plasma & Pulsed Plasma \\
$\begin{array}{c}\mathrm{promoted} \\
\mathrm{Ru} / \mathrm{MgO}\end{array}$ & 2.5 & - & $2.8-3.3$ & $313-563$ & - \\
$\mathrm{Ru} / \mathrm{MgO}$ & 9.2 & 1.5 & - & - & $101-141$ \\
promoted & 62 & 3.3 & - & - & - \\
\hline
\end{tabular}




\subsubsection{Best-Case Scenario for Plasma Catalysis}

As shown in Figure 3, the energy costs of the state-of-the-art system for plasma catalysis and recycling are high (about $197 \mathrm{GJ} \mathrm{t}-\mathrm{NH}_{3}{ }^{-1}$ ). Furthermore, the energy cost for recycling scales with the reciprocal of the single pass conversion. This implies that increasing the conversion by catalyst optimization and plasma optimization inherently decreases the energy cost of the recycle. An ammonia concentration of about $1.0 \mathrm{~mol}$. \% is required to effectively use the reactor volume for separation, as will be discussed in Section 3.1.

A target of $40 \mathrm{GJ} \mathrm{t}-\mathrm{NH}_{3}{ }^{-1}$ at $1.0 \mathrm{~mol}$. \% ammonia outlet concentration was set for the plasma reactor (see Section 1.2.1). The lowest energy consumption reported so far is for a pulsed plasma DBD reactors with an energy consumption of $95 \mathrm{GJ} \mathrm{t}-\mathrm{NH}_{3}{ }^{-1}$ at $0.16 \mathrm{~mol}$. \% over a $\mathrm{Mg}-\mathrm{Ru} / \mathrm{Al}_{2} \mathrm{O}_{3}$ catalyst [43]. Thus, an energy consumption enhancement by a factor 2.4 is required, whereas the conversion should increase by a factor 6.3 to attain feasible operation. Based on trends in thermal catalysis, a rate enhancement is expected by changing the catalyst from promoted $\mathrm{Ru} / \mathrm{Al}_{2} \mathrm{O}_{3}$ to promoted $\mathrm{Ru} / \mathrm{MgO}$ (see Table 1). It should be noted that the plasma activation of $\mathrm{NH}_{3}$ is an inherent limitation to the energy efficiency at high conversions, as $\mathrm{NH}_{3}$ is increasingly activated by the plasma with increasing $\mathrm{NH}_{3}$ concentration.

In order to get an estimate of the best-case scenario (BCS) for plasma-catalytic ammonia synthesis, we assume the barrier decrease for $\mathrm{N}_{2}$ dissociation equals the energy input for plasma-catalytic $\mathrm{NH}_{3}$ synthesis. The decrease in the $\mathrm{N}_{2}$ dissociation barrier over $\mathrm{Ru}$ catalysts is about $0.7 \mathrm{eV}$ [38], which translates to about $4.0 \mathrm{GJ} \mathrm{t}-\mathrm{NH}_{3}{ }^{-1}$ or $1.1 \mathrm{kWh} \mathrm{kg}^{-1}$. From Figure 6, it follows that an ammonia outlet concentration of 0.35 mol. \% is required to attain an energy cost of $40 \mathrm{GJ} \mathrm{t}-\mathrm{NH}_{3}{ }^{-1}$. For $1.0 \mathrm{~mol} . \% \mathrm{NH}_{3}$ concentration at the reactor outlet, the total energy consumption for the plasma reactor (BCS) and the recycling is about $5.0 \mathrm{GJ} \mathrm{t}^{-\mathrm{NH}_{3}}{ }^{-1}$ (see Figure 6).

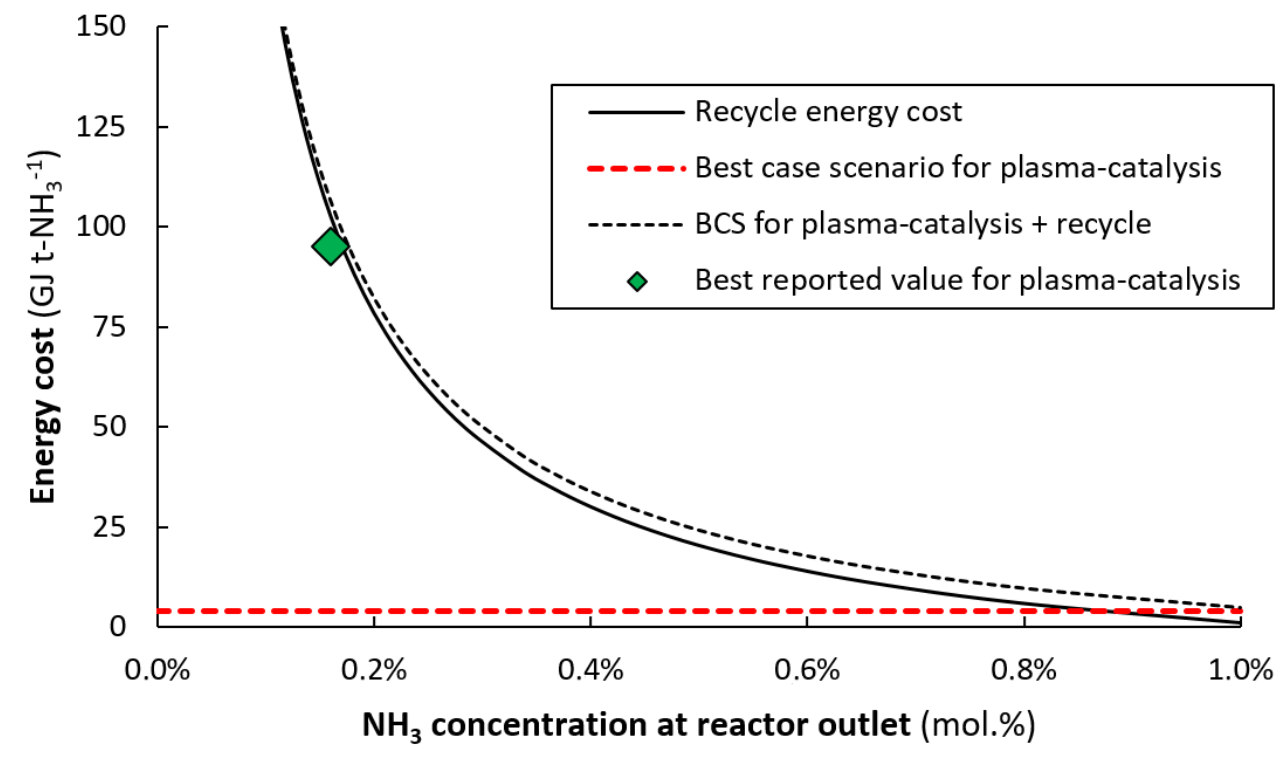

Figure 6. Energy cost of the recycle as a function of the ammonia concentration at the reaction outlet, as well as the best reported value for plasma catalysis, and a best-case scenario for plasma catalysis. The energy cost of recycling is estimated based on values reported by Smith et al. [67]. The best reported value for plasma catalysis is found in the data of Kim et al. [43].

\section{Ammonia Separation and Conceptual Process Design}

An evaluation of various process alternatives for ammonia separation in a plasma-catalytic ammonia synthesis process is presented. The cost of such a small-scale process is compared to a small-scale Haber-Bosch synthesis loop. As hydrogen and nitrogen production occur in a similar manner, this is not discussed here. 


\subsection{Separation and Storage}

Ammonia is conventionally separated by condensation. However, this does not allow for efficient and complete separation at low operating pressures, as ammonia has a significant vapor pressure under ambient conditions ( $\sim 7$ bar). Therefore, an alternative method for ammonia separation is required for ammonia synthesis under mild pressures [67]. Solid sorbents can be used for this purpose and a wide range of materials has been tested [66].

Among these sorbents, metal halides (e.g., metal chlorides and metal bromides) and zeolites are most promising (see Table 2). A benefit of metal halides over zeolites is the higher ammonia density of the storage material. Furthermore, ammonia can be separated at elevated temperatures using metal halides, minimizing the temperature difference between the plasma reactor and the separation step. This saves on the cost of heat integration between the plasma reactor (probably $200-300{ }^{\circ} \mathrm{C}$ ) and the separation step, i.e., $150-250{ }^{\circ} \mathrm{C}$ for metal halides, as compared to $20-100{ }^{\circ} \mathrm{C}$ for zeolites. For low conversion systems such as plasma-catalytic ammonia synthesis, the investment cost of the recycle compressor and heat exchanger generally dominate the investment cost for the synthesis loop [67]. Therefore, metal halides are the preferred option in this case. However, it should be noted that zeolites are of interest if plasma-catalytic ammonia synthesis at room temperature is developed with plasma-activated $\mathrm{N}_{2}$ as the relevant species.

Table 2. Comparison of ammonia separation technologies. Based on references [16,80-83]. * The energy consumption increases to $20-25 \mathrm{GJ} \mathrm{t}^{-\mathrm{NH}_{3}}{ }^{-1}$ at 20 bar [67].

\begin{tabular}{llll}
\hline & Condensation & Metal Halides & Zeolites \\
\hline Separation temperature $\left({ }^{\circ} \mathrm{C}\right)$ & -20 to 30 & $150-250$ & $20-100$ \\
Desorption temperature $\left({ }^{\circ} \mathrm{C}\right)$ & - & $350-400$ & $200-250$ \\
Pressure (bar) & $100-450$ & $10-30$ & $10-30$ \\
Energy consumption $\left(\mathrm{GJ} \mathrm{t}-\mathrm{NH}_{3}{ }^{-1}\right)$ & $3-5^{*}$ & $6-11$ & 8 \\
Ammonia at outlet $(\mathrm{mol} \%)$ & $2-5$ & $0.1-0.3$ & $0.1-0.3$ \\
Ammonia capacity $(\mathrm{wt} . \%)$ & 100 & $5-30$ & $5-15$ \\
Ammonia density $\left(\mathrm{kg} \mathrm{m}^{-3}\right)$ & 680 & $100-600$ & $30-90$ \\
Chemical stability & - & Low/Medium & High \\
Technology readiness level (TRL) & 9 & $4-5$ & $4-5$ \\
\hline
\end{tabular}

Ammonia can be stored inside the metal halides. Metal halides absorb ammonia via diffusion of ammonia into the lattice, forming an ammine complex. For instance, ammonia can be absorbed into $\mathrm{CaCl}_{2}$ and $\mathrm{MgCl}_{2}$, forming $\mathrm{Ca}\left(\mathrm{NH}_{3}\right)_{\mathrm{X}} \mathrm{Cl}_{2}$ and $\mathrm{Mg}\left(\mathrm{NH}_{3}\right)_{\mathrm{X}} \mathrm{Cl}_{2}$. Ammonia leakage risks are reduced as compared to liquefied ammonia, as the ammonia vapor pressure in equilibrium with the ammonia loaded metal halides is significantly lower as compared to the vapor pressure of pure ammonia [84]. This decreases safety risks substantially. Thus, ammonia is stored inside metal halides, until ammonia is required for combustion in for instance a fuel cell or engine [16]. A simplified process scheme of a plasma-catalytic ammonia synthesis loop is shown in Figure 7. The adsorption-desorption cycle can be achieved by switching between multiple beds or by using moving bed reactors. 


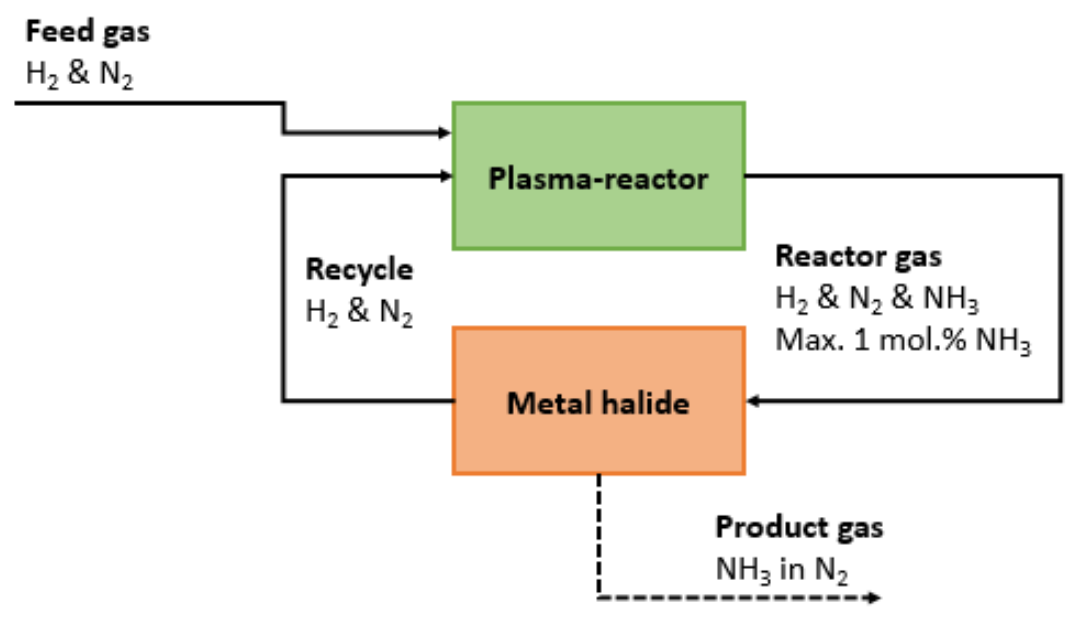

Figure 7. Process scheme of a plasma-catalytic ammonia synthesis loop.

\subsection{Synergy between Plasma Reactor and Ammonia Separation and Storage}

As discussed above, synergy may be attained upon matching the operating temperature of the plasma reactor and the ammonia separator. The plasma reactor can operate at temperatures above the light-off temperature (typically $>150^{\circ} \mathrm{C}$ ), where a higher temperature implies a higher ammonia synthesis rate. On the other hand, upon increasing the temperature too much (i.e., above $300{ }^{\circ} \mathrm{C}$ ), the benefits of plasma catalysis over heterogeneous catalysis without a plasma are negligible. Some catalysts show substantial thermal activity above $300{ }^{\circ} \mathrm{C}$ [85-88], which implies that the use of plasma is not necessary.

Among metal halides, $\mathrm{MgCl}_{2}$ shows suitable absorption-desorption cycles. At an ammonia partial pressure of $10 \mathrm{kPa}$ and at $200{ }^{\circ} \mathrm{C}$, two moles of ammonia can be absorbed in $\mathrm{MgCl}_{2}$, forming $\mathrm{Mg}\left(\mathrm{NH}_{3}\right)_{2} \mathrm{Cl}_{2}$. Upon increasing the temperature to $300{ }^{\circ} \mathrm{C}$, all ammonia can be released again. As ammonia absorption is determined by the kinetic rate of the surface reaction [89], maximizing the available $\mathrm{MgCl}_{2}$ surface area is beneficial. Supporting $\mathrm{MgCl}_{2}$ on an inert oxide can increase the available surface area of $\mathrm{MgCl}_{2}$. Furthermore, nano-pores are formed in the metal halide structure upon ammonia desorption. Possibly, the mechanical stability can be better maintained upon supporting $\mathrm{MgCl}_{2}$ on an inert oxide. Higher ammonia absorption capacities are obtained when loading metal halides on oxide supports [82]. $\mathrm{MgCl}_{2} / \mathrm{SiO}_{2}\left(40 \mathrm{wt}\right.$. $\% \mathrm{MgCl}_{2}$ ) is the best among the tested materials with an experimental sorbent capacity of about $5 \mathrm{wt}$. $\%$ ammonia at $200{ }^{\circ} \mathrm{C}$, whereas the theoretical maximum is $11 \mathrm{wt}$ \% ammonia.

The operating conditions and the energy consumption for the state-of-the-art plasma reactor and a best-case scenario (BCS) plasma reactor are listed in Table 3, as well as the operating conditions for ammonia separation with a $\mathrm{MgCl}_{2} / \mathrm{SiO}_{2}$ sorbent. Due to the similar reaction conditions in the plasma reactor and in the absorption step, heat integration can indeed be minimized. This simplifies the synthesis loop substantially in case of intermittent operation. From Table 3 it follows that the main improvement required is the energy consumption in the plasma reactor, as was also discussed in Section 2.2.2. 
Table 3. Synergy between plasma and ammonia separation and storage. * This includes the energy consumption for plasma-catalytic ammonia synthesis (PC) and the energy consumption for recycling (Rec). The energy consumption for recycling is based on the outlet $\mathrm{NH}_{3}$ concentration, based on interpolation of estimates in $[16,67]$. The state-of-the-art value for plasma catalysis is based on the data of Kim et al. [43], while the best-case scenario is based on an energy input of $0.7 \mathrm{eV}$ due to a decrease in the $\mathrm{N}_{2}$ dissociation barrier over Ru catalysts (see Section 2.2) [38]. The difference between the operating pressure of the plasma reactor and the separation step is to account for the pressure drop over the system.

\begin{tabular}{llll}
\hline & State-of-the-Art Plasma Reactor & BCS Plasma Reactor & Separation \\
\hline Type & DBD reactor (pulse) & DBD reactor (pulse) & Solid absorbent \\
Material & Promoted Ru/Al $\mathrm{O}_{3}$ catalyst & More active catalyst & $\mathrm{MgCl}_{2} / \mathrm{SiO}_{2}$ \\
Reaction temperature $\left({ }^{\circ} \mathrm{C}\right)$ & 300 & 200 & 200 \\
Desorption temperature $\left({ }^{\circ} \mathrm{C}\right)$ & - & - & 300 \\
Operating pressure $(\mathrm{bar})$ & 1.5 & 1.5 & 1.0 \\
Outlet $\mathrm{NH}_{3}$ concentration $(\mathrm{mol} . \%)$ & 0.16 & 1.0 & 0.1 \\
Outlet ammonia pressure $\left(\mathrm{kPa}^{2}\right)$ & 1.6 & 10 & 0.3 \\
Energy consumption $\left(\mathrm{GJ} \mathrm{t}-\mathrm{NH}_{3}{ }^{-1}\right)$ & $197(\mathrm{PC}: 95$, Rec:102) & $5(\mathrm{PC}: 4, \mathrm{Rec}: 1)$ & 10 \\
Syngas ratio $\left(\mathrm{H}_{2}: \mathrm{N}_{2}\right)$ & $1: 4$ & $1: 4$ & $1: 4$ \\
\hline
\end{tabular}

\subsection{Investment Cost Comparison}

Most of the discussion so far has focused on the energy consumption in the ammonia synthesis loop, as the energy cost is usually the major cost contributor for electricity-driven ammonia synthesis [90]. Given that the energy consumption of small-scale systems is larger, the electricity cost is expected to be a major cost contributor in small-scale systems as well. However, investment costs can become substantial cost factors as well. In this section, an estimate is provided on the capital investment for plasma-catalytic ammonia synthesis as compared to a decentralized Haber-Bosch synthesis loop. As hydrogen and nitrogen are required for both a small-scale Haber-Bosch process and a plasma-catalytic ammonia synthesis process, the costs for hydrogen production and nitrogen purification are excluded in the analysis.

The capital investment for the ammonia synthesis loop scales with a cost-scaling factor of 0.6 [14], while electrolyzers scale modularly. Thus, the contribution of the ammonia synthesis loop to the total cost increases upon scale-down. Figure 8 shows a comparison between the capital investment for the Haber-Bosch synthesis loop, the state-of-the-art plasma-catalytic ammonia synthesis loop, and a best-case scenario for the plasma-catalytic ammonia synthesis loop. For reference, the capital investment for a low-temperature, absorbent-enhanced Haber-Bosch synthesis loop is also shown. The equipment cost for the plasma generator is estimated to be $0.9 € \mathrm{~W}^{-1}$, based on estimates of van Rooij et al. [91]. The equipment cost of all other components are estimated, based on cost-scaling relations described in [67].

The investment cost of the state-of-the-art plasma-catalytic ammonia synthesis loop is about ten times as high as that of the small-scale Haber-Bosch synthesis loop. The main reason for this is the large recycle, implying a large compressor is required. Furthermore, separation of ammonia is less efficient at low ammonia concentrations, implying large equipment for ammonia absorption. Even for the best-case scenario with minimal heat exchange between the reactor and the sorbent, plasma-catalytic ammonia synthesis is equally expensive as the Haber-Bosch synthesis loop. The high-pressure Haber-Bosch synthesis loop requires a large feed compressor, as well as substantial heat integration between ammonia synthesis at $400-500{ }^{\circ} \mathrm{C}$ and ammonia separation at near-ambient temperature. On the other hand, the cost of ammonia separation and the recycle compressor are low due to high ammonia partial pressures and relatively high single pass conversions of about $15 \%$. The best-case scenario plasma-catalytic synthesis loop operates at low pressures, thereby eliminating the requirement for a feed compressor. However, the recycle compressor is more expensive, due to low single pass conversions of about $1 \%$. Furthermore, the low ammonia partial pressure also leads to more expensive ammonia separation equipment. 


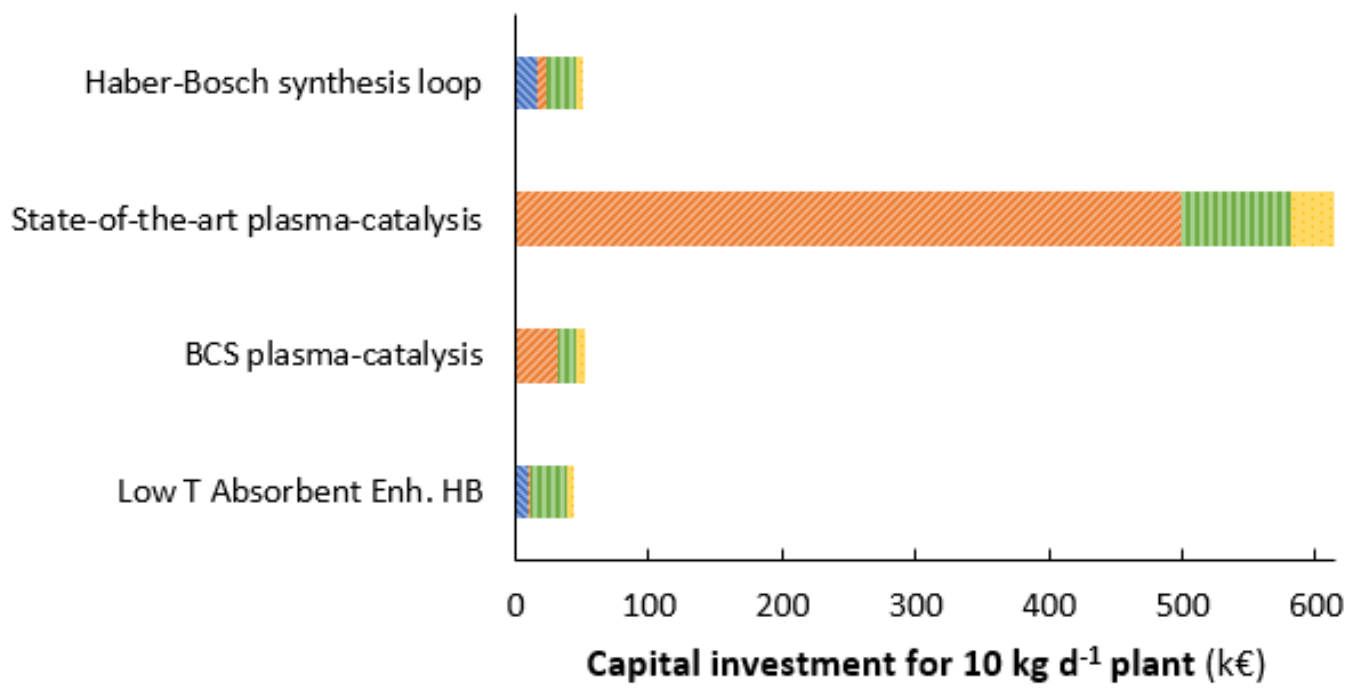

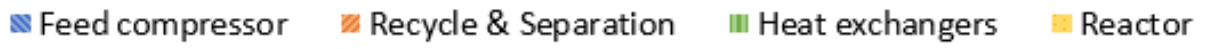

Figure 8. Capital investment for the conventional Haber-Bosch synthesis loop, state-of-the-art plasma catalysis, a best-case scenario for plasma catalysis, and an absorbent-enhanced Haber-Bosch synthesis loop at $10 \mathrm{~kg} \mathrm{t}-\mathrm{NH}_{3} \mathrm{~d}^{-1}(\sim 10 \mathrm{~kW})$. Estimates for the conventional Haber-Bosch synthesis loop and the absorbent-enhanced Haber-Bosch synthesis loop are based on [67]. The cost of the plasma reactor is assumed to be the combination of a conventional reactor and a plasma generator source. A cost-scaling factor of 0.6 is used for scale-down of equipment. See also Table 3.

\section{Plasma-Catalytic Ammonia Synthesis in Perspective}

All in all, it can be concluded that plasma-catalytic ammonia synthesis does not provide significant investment cost advantages over the Haber-Bosch synthesis loop on a small scale (about $10 \mathrm{~kW}$ ), even in the best base scenario (see Section 3.3). The energy consumption of the best-case scenario for plasma-catalytic ammonia synthesis is lower than that of the Haber-Bosch process at $10 \mathrm{~kW}$ (see Figure 9). At larger scale, the Haber-Bosch process is more energy efficient in any case (see Figure 3), implying plasma-catalytic ammonia synthesis is not a viable alternative.

In the previous sections, the focus was on improvements of plasma-catalytic ammonia synthesis. However, a wide range of technology is currently being researched as an alternative to the Haber-Bosch process on a small scale. Electrochemical synthesis, photochemical synthesis, homogeneous catalysis, and chemical looping approaches have been reported. The estimated state-of-the-art energy consumption for these technologies is shown in Figure 9. An extensive account on these technologies is given by Rouwenhorst et al. [66]. Electrochemical ammonia synthesis is often proposed as an alternative to ammonia synthesis under mild conditions. However, producing significant ammonia concentrations at a low energy cost has proven to be difficult [92-94]. Even if ammonia is produced at a sufficiently low energy cost, the conversion levels and separation of ammonia from the electrolyte become key issues [95]. None of the other technologies can be implemented on a near-term, due to high energy cost and low ammonia yields obtained [66].

Gradual improvements to the Haber-Bosch process have gained considerable research interest as well. The current industrial multiple promoted iron catalyst has been developed over the past century with minor changes in catalyst formulation and optimization of catalyst preparation [96,97]. On the other hand, activated carbon supported Ru catalysts ( $\mathrm{Ru} / \mathrm{AC}$ ) have also been implemented in industry to a lesser extent [7]. The implementation of $\mathrm{Ru} / \mathrm{AC}$ has been limited, due to a higher catalyst cost and a shorter catalyst lifetime than iron-based catalysts. For the industrial iron-based catalysts and the first generation of Ru-based catalysts ( $\mathrm{Ru} / \mathrm{AC}, \mathrm{Ru} / \mathrm{Oxide}), \mathrm{N}_{2}$ dissociation is the rate limiting step, which can be enhanced by the introduction of alkali and alkaline earth promoters [74]. In various cases, 
ruthenium-based catalysts have been replaced by wüstite-based iron catalysts in ammonia converters, because these catalysts show similar activity [96]. A catalyst that is active at substantially lower temperatures is required to replace iron-based catalysts. Operation at lower temperatures can minimize heat loss to the surroundings during a small-scale operation and lower the required energy input.

Over the past years, Ru-based catalysts with substantially improved activity have been developed by using new support materials, such as electrides, among others [77,85-87,98-105]. The $\mathrm{C}_{12} \mathrm{~A}_{7}: \mathrm{e}^{-}$structure used is an electride, stable at ambient temperature, consisting of a positively charged framework with the chemical formula $\left[\mathrm{Ca}_{24} \mathrm{Al}_{28} \mathrm{O}_{64}\right]^{4+}$ and four extra-framework electrons, accommodated in the cages as counter ions [106]. It has been proposed that the $\mathrm{N}_{2}$ dissociation rate is enhanced on electride supported Ru catalyst, due to a small band gap between the valence band of the electride and the conduction band of the metal [100]. Furthermore, the hydrogen poisoning effect commonly encountered for Ru catalysts is thought to be suppressed [99]. For these catalysts, hydrogenation over the catalyst is the rate-limiting step, rather than the $\mathrm{N}_{2}$ dissociation step [101]. These catalysts show activity at $200-250{ }^{\circ} \mathrm{C}$, similar to that of industrial Fe-based catalysts at $350-400{ }^{\circ} \mathrm{C}$ [85]. These highly active Ru-based catalysts are clearly a competitive alternative to a plasma reactor, as these catalysts are sufficiently active to decrease the reactor temperature similarly to plasma-catalytic ammonia synthesis. Furthermore, plasma catalysis can only be employed at a high energy efficiency (i.e., a low energy consumption), when ammonia conversions are low, as the plasma also activates the product and we expect $\mathrm{NH}_{3}$ concentrations should be limited to about $1.0 \mathrm{~mol}$ \% in order to limit plasma activation of the product. This problem is not present for the new generation of Ru-based catalysts, which no longer have the $\mathrm{N}_{2}$ dissociation as the rate-limiting step. Solid sorbents such as metal halides can also be combined with the new generation of Ru-based catalysts, thereby allowing to decrease the pressure of the ammonia synthesis loop to that of the hydrogen production and nitrogen purification pressure (about 7 bar) [16]. This is coined the absorbent-enhanced Haber-Bosch process.

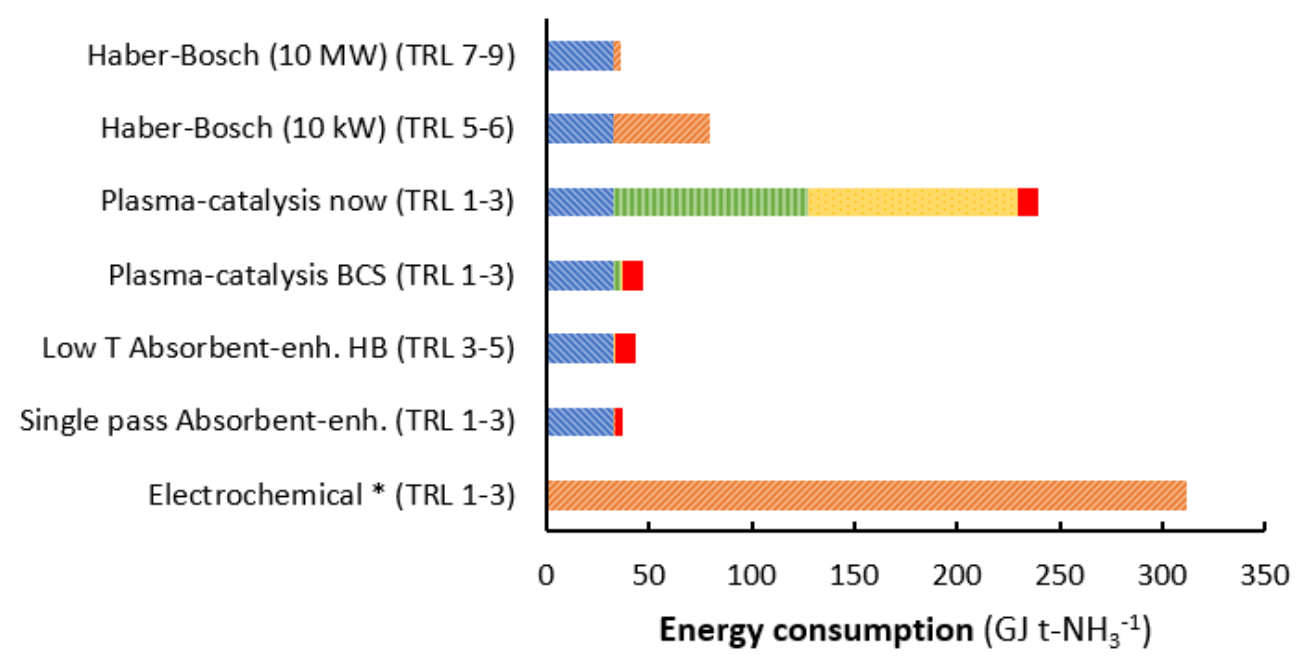

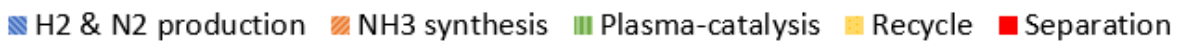

Figure 9. Estimated energy consumption of state-of-the-art small-scale, electrolysis-based Haber-Bosch, plasma catalysis (also best-case scenario), absorbent-enhanced Haber-Bosch, single pass process absorbent-enhanced process, and electrochemical ammonia synthesis. Estimates based on $[16,67,107,108]$. For plasma catalysis, the energy consumption for gas recycling and ammonia separation is based on estimates in for low pressure (1.5 bar), low conversion $\left(0.4 \mathrm{~mol} . \% \mathrm{NH}_{3}\right)$ systems with solid sorbents (see also Section 3.1) [16,67]. * For electrochemical ammonia synthesis, only the energy consumption of ammonia production is included and the energy cost of ammonia separation and recycling is not included. TRL stands for technology readiness level. The TRL levels here apply for the complete system. TRL 1 is the basic idea, while TRL 9 is a commercial system. For more details, see ref. [68]. 
Even for the best-case scenario (BCS) for plasma catalysis with a 5.8 times improvement in energy consumption for plasma catalysis (see Section 2.2.2), the energy consumption for a plasma-catalytic ammonia synthesis process is higher than for a low temperature synthesis, absorbent-enhanced Haber-Bosch process (see Figure 9). Furthermore, the capital investment for a plasma-catalytic process is expected to be higher than for the absorbent-enhanced Haber-Bosch process, because of the required larger heat exchanger and larger recycle compressor, due to a lower single pass conversion [67]. For reference, the electrolysis-based Haber-Bosch process at $10 \mathrm{MW}$ has a power-to-ammonia efficiency of $52 \%$ (LHV), while the best-case scenario for plasma catalysis has a power-to-ammonia efficiency of $39 \%$ (LHV). The current energy consumption for plasma-catalytic ammonia synthesis is about $240 \mathrm{GJ}$ $\mathrm{t}-\mathrm{NH}_{3}{ }^{-1}$, leading to a power-to-ammonia efficiency as low as $8 \%$ (LHV).

\section{Outlook}

Plasma-catalytic ammonia synthesis does not appear to be a feasible alternative to long-term energy storage in $\mathrm{NH}_{3}$. In case of $\mathrm{N}_{2}$ activation for ammonia synthesis, alternative technologies under development for ammonia synthesis appear to be more feasible in the short term and in the long term (see Section 4). Ammonia synthesis from hydrogen and nitrogen is an exothermic reaction and an exergonic reaction and under most conditions [73], implying plasma activation is, in principle, not desirable.

However, plasma catalysis is an interesting alternative to electrifying in the chemical industry, due to the ability of plasma to activate strong chemical bonds such as $\mathrm{CH}_{4}, \mathrm{CO}_{2}$ and $\mathrm{N}_{2}$ [28]. For instance, the bond dissociation energy of the $\mathrm{N} \equiv \mathrm{N}$ is $9.79 \mathrm{eV}$, while electrons in DBD reactors typically have energies in the range $2-4 \mathrm{eV}$. The total barrier for $\mathrm{CH}_{4}$ activation can be decreased upon vibrational excitation [109], thereby increasing the dissociative sticking probability [110]. Furthermore, plasma-assisted technologies have a fast response to electricity load variations. The plasma may provide very localized heating, thus limiting the heat requirement for the reactor. This can be beneficial for endergonic reactions. Lastly, plasma activation has the potential to provide process intensification. For instance, $\mathrm{N}_{2}$ activation with a plasma can be of interest for the direct synthesis of $\mathrm{NO}_{\mathbf{X}}[111,112]$, thereby eliminating the ammonia synthesis step altogether. As discussed in this article, the product outlet concentration should typically be above $1.0 \mathrm{~mol}$ \%, in order to limit the recycle size and to allow for efficient product separation.

Author Contributions: Conceptualization, K.H.R.R.; methodology, K.H.R.R., L.L.; formal analysis, K.H.R.R.; investigation, K.H.R.R.; writing一original draft preparation, K.H.R.R.; writing一review and editing, K.H.R.R., L.L.; visualization, K.H.R.R.; supervision, L.L.; funding acquisition, L.L. All authors have read and agreed to the published version of the manuscript.

Funding: This research was funded by Toeslag voor Topconsortia voor Kennis en Innovatie (TKI) from the Ministry of Economic Affairs and Climate Policy.

Conflicts of Interest: The authors declare no conflict of interest.

\section{References}

1. Van Geem, K.M.; Galvita, V.V.; Marin, G.B. Making chemicals with electricity. Science 2019, 364, 734-735. [CrossRef] [PubMed]

2. Simon, E. Green ammonia. In Proceedings of the REFUEL Kickoff Meeting, Denver, CO, USA, 17-18 August 2017; Available online: https://arpa-e.energy.gov/sites/default/files/04cDenver-GreenAmmonia-Siemensfinal.pdf (accessed on 1 September 2019).

3. Valera-Medina, A.; Xiao, H.; Owen-Jones, M.; David, W.I.F.; Bowen, P. Ammonia for power. Prog. Energy Combust. Sci. 2018, 69, 63-102. [CrossRef]

4. Hunt, J.D.; Byers, E.; Wada, Y.; Parkinson, S.; Gernaat, D.E.H.J.; Langan, S.J.; Van Vuuren, D.P.; Riahi, K. Global resource potential of seasonal pumped hydropower storage for energy and water storage. Nat. Commun. 2020, 11, 1-8. [CrossRef] [PubMed]

5. Guo, J.; Chen, P. Catalyst: NH3 as an Energy Carrier. Chem 2017, 3, 709-712. [CrossRef] 
6. Nielsen, A. Ammonia: Catalysis and Manufacture, 1st ed.; Nielsen, A., Ed.; Springer: Berlin/Heidelberg, Germany, 1995.

7. Liu, H. Ruthenium Based Ammonia Synthesis Catalysts; World Scientific Pub Co Pte Ltd.: Singapore, 2013; pp. 425-542.

8. Jennings, J.M. Catalytic Ammonia Synthesis: Fundamentals and Practice, 1st ed.; Plenum Press: New York, NY, USA, 1991.

9. Avery, W. A role for ammonia in the hydrogen economy. Int. J. Hydrogen Energy 1988, 13, 761-773. [CrossRef]

10. Christensen, C.H.; Johannessen, T.; Sørensen, R.Z.; Nørskov, J.K. Towards an ammonia-mediated hydrogen economy? Catal. Today 2006, 111, 140-144. [CrossRef]

11. Appl, M. Ammonia, 2. Production Processes. In Ullmann's Encyclopedia of Industrial Chemistry; Wiley: Hoboken, NJ, USA, 2012. [CrossRef]

12. European Fertilizer Manufacturers' Association. Production of Ammonia. Best Available Techniques for Pollution Prevention and Control in the European Fertilizer Industry; European Fertilizer Manufacturers' Association: Brussels, Belgium, 2000; Available online: https://www.ocinitrogen.com/MediaLibrary/Ammoniaprocess--BATProductionofammonia(2000)---Brochure.pdf (accessed on 1 September 2019).

13. Brightling, J. Ammonia and the Fertiliser Industry: The Development of Ammonia at Billingham. Johns. Matthey Technol. Rev. 2018, 62, 32-47. [CrossRef]

14. Rouwenhorst, K.H.R.; Krzywda, P.M.; Benes, N.E.; Mul, G.; Lefferts, L. Ammonia, 4. Green Ammonia Production. In Ullmann's Encyclopedia of Industrial Chemistry; Wiley: Hoboken, NJ, USA, 2012. [CrossRef]

15. Proton Ventures, B.V. Sustainable ammonia for food and power. In Proceedings of the Nitrogen + Syngas, Gotheburg, Sweden, 6 February-1 March 2018; pp. 1-10. Available online: http://www.protonventures.com/ wp-content/uploads/2018/09/NS-354-Small-scale-plant-design-PROTON-VENTURES-3-1.pdf (accessed on 1 September 2019).

16. Rouwenhorst, K.H.R.; Van Der Ham, A.G.J.; Mul, G.; Kersten, S.R. Islanded ammonia power systems: Technology review \& conceptual process design. Renew. Sustain. Energy Rev. 2019, 114. [CrossRef]

17. Vrijenhoef, H. Dutch initiatives to store sustainable energy in the form of ammonia. In Proceedings of the $\mathrm{NH}_{3}$ Fuel Conference, Minneapolis, MN, USA, 1-2 November 2017; Available online: https://nh3fuelassociation. org/2017/09/25/dutch-initiatives-to-store-sustainable-energy-in-the-form-of-ammonia/ (accessed on 1 September 2019).

18. Reese, M.; Marquart, C.; Malmali, M.; Wagner, K.; Buchanan, E.; McCormick, A.; Cussler, E.L. Performance of a Small-Scale Haber Process. Ind. Eng. Chem. Res. 2016, 55, 3742-3750. [CrossRef]

19. Brown, T. Ammonia Technology Portfolio: Optimize for Energy Efficiency and Carbon Efficiency. Available online: https://ammoniaindustry.com/ammonia-technology-portfolio-optimize-for-energy-efficiency-andcarbon-efficiency/ (accessed on 23 March 2018).

20. Morgan, E.R.; Manwell, J.F.; McGowan, J.G. Sustainable Ammonia Production from U.S. Offshore Wind Farms: A Techno-Economic Review. ACS Sustain. Chem. Eng. 2017, 5, 9554-9567. [CrossRef]

21. Pfromm, P.H. Towards sustainable agriculture: Fossil-free ammonia. J. Renew. Sustain. Energy 2017, 9, 034702. [CrossRef]

22. Will, M. Realisation of Large-Scale Green Ammonia Plants. In Proceedings of the NH3 Fuel Conference, Pittsburgh, PA, USA, 31 October-1 November 2018.

23. Will, M.; Lüke, L. Realisation of large-scale Green Ammonia plants. In Proceedings of the NH3 Event, Rotterdam, The Netherlands, 2-5 June 2018; Available online: https://nh3event.com/day-2/ (accessed on 15 July 2018).

24. Vrijenhoef, J.P. Opportunities for Small scale Ammonia Production; International Fertiliser Society: London, UK, 2017; pp. 1-16. Available online: http://www.protonventures.com/wp-content/uploads/2017/07/PaperOpportunities-for-small-scale-ammonia-production_ProtonVentures_HansVrijenhoef.pdf (accessed on 1 September 2019).

25. Schmuecker, J.; Toyne, D. Making demonstration amounts of renewable ammonia and using it to fuel a farm tractor. In Proceedings of the NH3 Event, Rotterdam, The Netherlands, 6-7 June 2019.

26. Hansen, J.B.; Han, P. The SOC4NH3 Project in Denmark. In Proceedings of the NH3 Event, Rotterdam, The Netherlands, 6-7 June 2019.

27. Bogaerts, A.; Neyts, E.C. Plasma Technology: An Emerging Technology for Energy Storage. ACS Energy Lett. 2018, 3, 1013-1027. [CrossRef] 
28. Mehta, P.; Barboun, P.; Go, D.B.; Hicks, J.C.; Schneider, W.F. Catalysis Enabled by Plasma Activation of Strong Chemical Bonds: A Review. ACS Energy Lett. 2019, 4, 1115-1133. [CrossRef]

29. Brandenburg, R.; Bogaerts, A.; Bongers, W.; Fridman, A.; Fridman, G.; Locke, B.R.; Miller, V.; Reuter, S.; Schiorlin, M.; Verreycken, T.; et al. White paper on the future of plasma science in environment, for gas conversion and agriculture. Plasma Process. Polym. 2018, 16, 1-18. [CrossRef]

30. Bogaerts, A.; Tu, X.; Whitehead, J.C.; Centi, G.; Lefferts, L.; Guaitella, O.; Azzolina-Jury, F.; Kim, H.-H.; Murphy, A.B.; Schneider, W.F.; et al. The 2020 Plasma Catalysis Roadmap. J. Phys. D Appl. Phys. 2020, 53, 1-51. [CrossRef]

31. Rouwenhorst, K.H.R.; Engelmann, Y.; van't Veer, K.; Postma, R.S.; Bogaerts, A.; Lefferts, L. Plasma-Driven catalysis: Green ammonia synthesis from intermittent electricity. Green Chem. 2020, in press.

32. Hong, J.; Prawer, S.; Murphy, A.B. Plasma Catalysis as an Alternative Route for Ammonia Production: Status, Mechanisms, and Prospects for Progress. ACS Sustain. Chem. Eng. 2017, 6, 15-31. [CrossRef]

33. Carreon, M.L. Plasma catalytic ammonia synthesis: State of the art and future directions. J. Phys. D Appl. Phys. 2019, 52, 483001. [CrossRef]

34. Kim, H.H.; Teramoto, Y.; Ogata, A.; Takagi, H.; Nanba, T. Plasma Catalysis for Environmental Treatment and Energy Applications. Plasma Chem. Plasma Process. 2015, 36, 45-72. [CrossRef]

35. Peng, P.; Chen, P.; Schiappacasse, C.; Zhou, N.; Anderson, E.; Chen, D.; Liu, J.; Cheng, Y.; Hatzenbeller, R.; Addy, M.; et al. A review on the non-thermal plasma-assisted ammonia synthesis technologies. J. Clean. Prod. 2018, 177, 597-609. [CrossRef]

36. Peng, P.; Schiappacasse, C.; Zhou, N.; Addy, M.; Cheng, Y.; Zhang, Y.; Ding, K.; Wang, Y.; Chen, P.; Ruan, R. Sustainable Non-Thermal Plasma-Assisted Nitrogen Fixation-Synergistic Catalysis. ChemSusChem 2019, 12, 3702-3712. [CrossRef]

37. Neyts, E.C. Plasma-Surface Interactions in Plasma Catalysis. Plasma Chem. Plasma Process. 2015, 36, 185-212. [CrossRef]

38. Rouwenhorst, K.H.R.; Kim, H.-H.; Lefferts, L. Vibrationally Excited Activation of N2 in Plasma-Enhanced Catalytic Ammonia Synthesis: A Kinetic Analysis. ACS Sustain. Chem. Eng. 2019, 7, 17515-17522. [CrossRef]

39. Barboun, P.M.; Mehta, P.; Herrera, F.A.; Go, D.B.; Schneider, W.F.; Hicks, J.C. Distinguishing Plasma Contributions to Catalyst Performance in Plasma-Assisted Ammonia Synthesis. ACS Sustain. Chem. Eng. 2019, 7, 8621-8630. [CrossRef]

40. Akay, G.; Zhang, K. Process Intensification in Ammonia Synthesis Using Novel Coassembled Supported Microporous Catalysts Promoted by Nonthermal Plasma. Ind. Eng. Chem. Res. 2017, 56, 457-468. [CrossRef]

41. Peng, P.; Cheng, Y.; Hatzenbeller, R.; Addy, M.; Zhou, N.; Schiappacasse, C.; Chen, D.; Zhang, Y.; Anderson, E.; Liu, Y.; et al. Ru-Based multifunctional mesoporous catalyst for low-pressure and non-thermal plasma synthesis of ammonia. Int. J. Hydrog. Energy 2017, 42, 19056-19066. [CrossRef]

42. Li, S.; Van Raak, T.; Gallucci, F. Investigating the operation parameters for ammonia synthesis in dielectric barrier discharge reactors. J. Phys. D Appl. Phys. 2019, 53, 014008. [CrossRef]

43. Kim, H.H.; Teramoto, Y.; Ogata, A.; Takagi, H.; Nanba, T. Atmospheric-Pressure nonthermal plasma synthesis of ammonia over ruthenium catalysts. Plasma Process. Polym. 2016, 14, 1600157. [CrossRef]

44. Shah, J.R.; Gorky, F.; Lucero, J.; Carreon, M.A.; Carreon, M.L. Ammonia Synthesis via Atmospheric Plasma Catalysis: Zeolite 5A, a Case of Study. Ind. Eng. Chem. Res. 2020, 59, 5167-5176. [CrossRef]

45. Iwamoto, M.; Akiyama, M.; Aihara, K.; Deguchi, T. Ammonia Synthesis on Wool-Like Au, Pt, Pd, Ag, or $\mathrm{Cu}$ Electrode Catalysts in Nonthermal Atmospheric-Pressure Plasma of $\mathrm{N}_{2}$ and $\mathrm{H}_{2}$. ACS Catal. 2017, 7, 6924-6929. [CrossRef]

46. Hong, J.; Prawer, S.; Murphy, A.B. Production of Ammonia by Heterogeneous Catalysis in a Packed-Bed Dielectric-Barrier Discharge: Influence of Argon Addition and Voltage. IEEE Trans. Plasma Sci. 2014, 42, 2338-2339. [CrossRef]

47. Gómez-Ramírez, A.M.; Cotrino, J.; Lambert, R.M.; González-Elipe, A.R. Efficient synthesis of ammonia from N2 and H2 alone in a ferroelectric packed-bed DBD reactor. Plasma Sources Sci. Technol. 2015, 24, 65011. [CrossRef]

48. Gómez-Ramírez, A.M.; Montoro-Damas, A.M.; Cotrino, J.; Lambert, R.M.; González-Elipe, A.R. About the enhancement of chemical yield during the atmospheric plasma synthesis of ammonia in a ferroelectric packed bed reactor. Plasma Process. Polym. 2016, 14, 1600081. [CrossRef] 
49. Mizushima, T.; Matsumoto, K.; Sugoh, J.-I.; Ohkita, H.; Kakuta, N. Tubular membrane-like catalyst for reactor with dielectric-barrier-discharge plasma and its performance in ammonia synthesis. Appl. Catal. A Gen. 2004, 265, 53-59. [CrossRef]

50. Srinath, N.V. Plasma Catalytic Ammonia Synthesis at Atmospheric Pressure in a Dielectric Barrier Discharge Reactor; Technische Universiteit Eindhoven: Eindhoven, The Netherlands, 2017; Available online: https: //pure.tue.nl/ws/files/91518802/Afstudeerverslag_Nadadur_Veeraraghavan_Srinath_0980194_.pdf (accessed on 1 September 2019).

51. Patil, B.S. Plasma (Catalyst)_Assisted Nitrogen Fixation: Reactor Development for Nitric Oxide and Ammonia Production; Technische Universiteit Eindhoven: Eindhoven, The Netherlands, 2017; Available online: https://pure.tue.nl/ws/files/64000562/20170510_Patil.pdf (accessed on 1 September 2019).

52. Peng, P.; Li, Y.; Cheng, Y.; Deng, S.; Chen, P.; Ruan, R. Atmospheric Pressure Ammonia Synthesis Using Non-Thermal Plasma Assisted Catalysis. Plasma Chem. Plasma Process. 2016, 36, 1201-1210. [CrossRef]

53. Peng, P.; Chen, P.; Addy, M.; Cheng, Y.; Anderson, E.; Zhou, N.; Schiappacasse, C.; Zhang, Y.; Chen, D.; Hatzenbeller, R.; et al. Atmospheric Plasma-Assisted Ammonia Synthesis Enhanced via Synergistic Catalytic Absorption. ACS Sustain. Chem. Eng. 2018, 7, 100-104. [CrossRef]

54. Yin, K.S.; Venugopalan, M. Plasma chemical synthesis. I. Effect of electrode material on the synthesis of ammonia. Plasma Chem. Plasma Process. 1983, 3, 343-350. [CrossRef]

55. Wildfire, C.; Abdelsayed, V.; Shekhawat, D.; Spencer, M.J. Ambient pressure synthesis of ammonia using a microwave reactor. Catal. Commun. 2018, 115, 64-67. [CrossRef]

56. Uyama, H.; Nakamura, T.; Tanaka, S.; Matsumoto, O. Catalytic effect of iron wires on the syntheses of ammonia and hydrazine in a radio-frequency discharge. Plasma Chem. Plasma Process. 1993, 13, $117-131$. [CrossRef]

57. Nakajima, J.; Sekiguchi, H. Synthesis of ammonia using microwave discharge at atmospheric pressure. Thin Solid Films 2008, 516, 4446-4451. [CrossRef]

58. Bai, X.; Tiwari, S.; Robinson, B.; Killmer, C.P.; Li, L.; Hu, J. Microwave catalytic synthesis of ammonia from methane and nitrogen. Catal. Sci. Technol. 2018, 8, 6302-6305. [CrossRef]

59. Siemsen, L.G. The Synthesis of Ammonia from Hydrogen and Atomic Nitrogen on the Rh(110) Surface; Iowa State University: Ames, IA, USA, 1990; Available online: https:/lib.dr.iastate.edu/cgi/viewcontent.cgi?article= 12220\&context $=\mathrm{rtd}$ (accessed on 1 September 2019).

60. Shah, J.; Gorky, F.; Psarras, P.; Seong, B.; Gómez-Gualdrón, D.A.; Carreon, M.L. Ammonia yield enhancement by hydrogen sink effect during plasma catalysis. ChemCatChem 2019, 12, 1200-1211. [CrossRef]

61. Shah, J.; Wu, T.; Lucero, J.; Carreon, M.A.; Carreon, M.L. Nonthermal Plasma Synthesis of Ammonia over Ni-MOF-74. ACS Sustain. Chem. Eng. 2018, 7, 377-383. [CrossRef]

62. Shah, J.; Wang, W.; Bogaerts, A.; Carreon, M.L. Ammonia Synthesis by Radio Frequency Plasma Catalysis: Revealing the Underlying Mechanisms. ACS Appl. Energy Mater. 2018, 1, 4824-4839. [CrossRef]

63. Uyama, H.; Uchikura, T.; Niijima, H.; Matsumoto, O. Synthesis of ammonia with RF discharge. Adsorption of products on zeolite. Chem. Lett. 1987, 16, 555-558. [CrossRef]

64. Uyama, H.; Matsumoto, O. Synthesis of ammonia in high-frequency discharges. Plasma Chem. Plasma Process. 1989, 9, 13-24. [CrossRef]

65. Shah, J.; Harrison, J.M.; Carreon, M.L. Ammonia Plasma-Catalytic Synthesis Using Low Melting Point Alloys. Catalysts 2018, 8, 437. [CrossRef]

66. Rouwenhorst, K.H.R.; Krzywda, P.M.; Benes, N.E.; Mul, G.; Lefferts, L. Green Ammonia Production. In Techno-Economic Challenges of Green Ammonia as Energy Vector; Bañares-Alcántara, R., Valera-Medina, A., Eds.; Elsevier: Amsterdam, The Netherlands, 2020.

67. Smith, C.; Hill, A.K.; Torrente-Murciano, L. Current and future role of Haber-Bosch ammonia in a carbon-free energy landscape. Energy Environ. Sci. 2020, 13, 331-344. [CrossRef]

68. Buchner, G.A.; Stepputat, K.J.; Zimmermann, A.W.; Schomäcker, R. Specifying Technology Readiness Levels for the Chemical Industry. Ind. Eng. Chem. Res. 2019, 58, 6957-6969. [CrossRef]

69. Eliasson, B.; Kogelschatz, U.; Xue, B.; Zhou, L.-M. Hydrogenation of Carbon Dioxide to Methanol with a Discharge-Activated Catalyst. Ind. Eng. Chem. Res. 1998, 37, 3350-3357. [CrossRef]

70. Teramoto, Y.; Kim, H.H. Effect of vibrationally excited $\mathrm{N}_{2}(\mathrm{v})$ on atomic nitrogen generation using two consecutive pulse corona discharges under atmospheric pressure $\mathrm{N}_{2}$. J. Phys. D Appl. Phys. 2019, 52, 494003. [CrossRef] 
71. Mehta, P.; Barboun, P.; Herrera, F.; Kim, J.; Rumbach, P.; Go, D.B.; Hicks, J.C.; Schneider, W.F. Overcoming ammonia synthesis scaling relations with plasma-enabled catalysis. Nat. Catal. 2018, 1, 269-275. [CrossRef]

72. Rouwenhorst, K.H.R.; Burbach, H.G.B.; Núñez Paulí, J.; Vogel, D.W.; Geerdink, B.; Lefferts, L. Plasma-Catalytic Ammonia Synthesis beyond Thermal Equilibrium over Ru-based Catalysts. In preparation.

73. Vojvodic, A.; Medford, A.J.; Studt, F.; Abild-Pedersen, F.; Khan, T.S.; Bligaard, T.; Nørskov, J. Exploring the limits: A low-pressure, low-temperature Haber-Bosch process. Chem. Phys. Lett. 2014, 598, 108-112. [CrossRef]

74. Aika, K.-I. Role of alkali promoter in ammonia synthesis over ruthenium catalysts—Effect on reaction mechanism. Catal. Today 2017, 286, 14-20. [CrossRef]

75. Ozaki, A. Development of alkali-promoted ruthenium as a novel catalyst for ammonia synthesis. Acc. Chem. Res. 1981, 14, 16-21. [CrossRef]

76. Mortensen, J.J.; Hammer, B.; Nørskov, J.K. Alkali Promotion of $\mathrm{N}_{2}$ Dissociation over Ru(0001). Phys. Rev. Lett. 1998, 80, 4333-4336. [CrossRef]

77. Inoue, Y.; Kitano, M.; Tokunari, M.; Taniguchi, T.; Ooya, K.; Abe, H.; Niwa, Y.; Sasase, M.; Hara, M.; Hosono, H. Direct Activation of Cobalt Catalyst by $12 \mathrm{CaO} \cdot 7 \mathrm{Al}_{2} \mathrm{O}_{3}$ Electride for Ammonia Synthesis. ACS Catal. 2019, 9, 1670-1679. [CrossRef]

78. Muhler, M.; Rosowski, F.; Hinrichsen, O.; Hornung, A.; Ertl, G. Ruthenium as catalyst for ammonia synthesis. Stud. Surf. Sci. Catal. 1996, 101, 317-326. [CrossRef]

79. Ruan, R.; Deng, S.; Le, Z.; Chen, P. Non-Thermal Plasma Synthesis of Ammonia; United States, 2009. Available online: https://patentimages.storage.googleapis.com/b8/04/25/03baed26ca11d4/WO2009025835A1. pdf (accessed on 1 September 2019).

80. Liu, C.Y.; Aika, K.-I. Effect of the Cl/Br Molar Ratio of a CaCl2-CaBr2 Mixture Used as an Ammonia Storage Material. Ind. Eng. Chem. Res. 2004, 43, 6994-7000. [CrossRef]

81. Beach, J.D.; Kintner, J.D.; Welch, A.W. Removal of Gaseous NH3 from an NH3 Reactor Product Stream. United States, 2018. Available online: https://patentimages.storage.googleapis.com/62/ef/a4/83ada6d54f30fe/ US20180339911A1.pdf (accessed on 1 September 2019).

82. Malmali, M.; Le, G.; Hendrickson, J.; Prince, J.; McCormick, A.V.; Cussler, E.L. Better Absorbents for Ammonia Separation. ACS Sustain. Chem. Eng. 2018, 6, 6536-6546. [CrossRef]

83. Liu, C.Y.; Aika, K.-I. Modification of active carbon and zeolite as ammonia separation materials for a new de-NOx process with ammonia on-site synthesis. Res. Chem. Intermed. 2002, 28, 409-417. [CrossRef]

84. Zhang, T.; Miyaoka, H.; Miyaoka, H.; Ichikawa, T.; Kojima, Y. Review on Ammonia Absorption Materials: Metal Hydrides, Halides, and Borohydrides. ACS Appl. Energy Mater. 2018, 1, 232-242. [CrossRef]

85. Kitano, M.; Inoue, Y.; Sasase, M.; Kishida, K.; Kobayashi, Y.; Nishiyama, K.; Tada, T.; Kawamura, S.; Yokoyama, T.; Hara, M.; et al. Self-Organized Ruthenium-Barium Core-Shell Nanoparticles on a Mesoporous Calcium Amide Matrix for Efficient Low-Temperature Ammonia Synthesis. Angew. Chem. 2018, 130, 2678-2682. [CrossRef]

86. Kitano, M.; Kanbara, S.; Inoue, Y.; Kuganathan, N.; Sushko, P.V.; Yokoyama, T.; Hara, M.; Hosono, H. Electride support boosts nitrogen dissociation over ruthenium catalyst and shifts the bottleneck in ammonia synthesis. Nat. Commun. 2015, 6, 6731. [CrossRef] [PubMed]

87. Kitano, M.; Inoue, Y.; Yamazaki, Y.; Hayashi, F.; Kanbara, S.; Matsuishi, S.; Yokoyama, T.; Kim, S.-W.; Hara, M.; Hosono, H. Ammonia synthesis using a stable electride as an electron donor and reversible hydrogen store. Nat. Chem. 2012, 4, 934-940. [CrossRef] [PubMed]

88. Shi, R.; Zhang, X.; Waterhouse, G.I.N.; Zhao, Y.; Zhang, T. The Journey toward Low Temperature, Low Pressure Catalytic Nitrogen Fixation. Adv. Energy Mater. 2020, 10. [CrossRef]

89. Smith, C.; Malmali, M.; Liu, C.-Y.; McCormick, A.V.; Cussler, E.L. Rates of Ammonia Absorption and Release in Calcium Chloride. ACS Sustain. Chem. Eng. 2018, 6, 11827-11835. [CrossRef]

90. Armijo, J.; Philibert, C. Flexible production of green hydrogen and ammonia from variable solar and wind energy: Case study of Chile and Argentina. Int. J. Hydrog. Energy 2020, 45, 1541-1558. [CrossRef]

91. Van Rooij, G.J.; Akse, H.N.; A Bongers, W.A.; Van De Sanden, M.C.M. Plasma for electrification of chemical industry: A case study on $\mathrm{CO}_{2}$ reduction. Plasma Phys. Control. Fusion 2017, 60, 014019. [CrossRef]

92. Singh, A.R.; Rohr, B.A.; Statt, M.J.; Schwalbe, J.A.; Cargnello, M.; Nørskov, J.K. Strategies toward Selective Electrochemical Ammonia Synthesis. ACS Catal. 2019, 9, 8316-8324. [CrossRef] 
93. Andersen, S.Z.; Čolić, V.; Yang, S.; Schwalbe, J.A.; Nielander, A.C.; McEnaney, J.M.; Enemark-Rasmussen, K.; Baker, J.; Singh, A.R.; Rohr, B.A.; et al. A rigorous electrochemical ammonia synthesis protocol with quantitative isotope measurements. Nature 2019, 570, 504-508. [CrossRef]

94. Kibsgaard, J.; Nørskov, J.K.; Chorkendorff, I. The Difficulty of Proving Electrochemical Ammonia Synthesis. ACS Energy Lett. 2019, 4, 2986-2988. [CrossRef]

95. Hollevoet, L.; De Ras, M.; Roeffaers, M.; Hofkens, J.; Martens, J.A. Energy-Efficient Ammonia Production from Air and Water Using Electrocatalysts with Limited Faradaic Efficiency. ACS Energy Lett. 2020, 5, 1124-1127. [CrossRef]

96. Liu, H.; Han, W.; Huo, C.; Cen, Y. Development and application of wüstite-based ammonia synthesis catalysts. Catal. Today 2019, 1-18. [CrossRef]

97. Mittasch, A.; Frankenburg, W. Early Studies of Multicomponent Catalysts. Adv. Catal. 1950, 2, 81-104. [CrossRef]

98. Hattori, M.; Iijima, S.; Nakao, T.; Hosono, H.; Hara, M. Solid solution for catalytic ammonia synthesis from nitrogen and hydrogen gases at $50^{\circ} \mathrm{C}$. Nat. Commun. 2020, 11, 1-8. [CrossRef] [PubMed]

99. Kammert, J.; Moon, J.; Cheng, Y.; Daemen, L.L.; Irle, S.; Fung, V.; Liu, J.; Page, K.; Ma, X.; Phaneuf, V.; et al. Nature of Reactive Hydrogen for Ammonia Synthesis over a Ru/C12A7 Electride Catalyst. J. Am. Chem. Soc. 2020, 142, 7655-7667. [CrossRef]

100. Hara, M.; Kitano, M.; Hosono, H. Ru-Loaded C12A7: $\mathrm{e}^{-}$Electride as a Catalyst for Ammonia Synthesis. ACS Catal. 2017, 7, 2313-2324. [CrossRef]

101. Kobayashi, Y.; Kawamura, S.; Kitano, M.; Yokoyama, T.; Hosono, H. Kinetic evidence: The rate-determining step for ammonia synthesis over electride-supported Ru catalysts is no longer the nitrogen dissociation step. Catal. Sci. Technol. 2017, 7, 47-50. [CrossRef]

102. Gong, Y.; Wu, J.; Kitano, M.; Wang, J.; Ye, T.-N.; Li, J.; Kobayashi, Y.; Kishida, K.; Abe, H.; Niwa, Y.; et al. Ternary intermetallic LaCoSi as a catalyst for $\mathrm{N}_{2}$ activation. Nat. Catal. 2018, 1, 178-185. [CrossRef]

103. Wu, J.; Li, J.; Gong, Y.; Kitano, M.; Inoshita, T.; Hosono, H. Intermetallic Electride Catalyst as a Platform for Ammonia Synthesis. Angew. Chem. Int. Ed. 2019, 58, 825-829. [CrossRef]

104. Inoue, Y.; Kitano, M.; Kishida, K.; Abe, H.; Niwa, Y.; Sasase, M.; Fujita, Y.; Ishikawa, H.; Yokoyama, T.; Hara, M.; et al. Efficient and Stable Ammonia Synthesis by Self-Organized Flat Ru Nanoparticles on Calcium Amide. ACS Catal. 2016, 6, 7577-7584. [CrossRef]

105. Gao, W.; Wang, P.; Guo, J.; Chang, F.; He, T.; Wang, Q.; Wu, G.; Chen, P. Barium Hydride-Mediated Nitrogen Transfer and Hydrogenation for Ammonia Synthesis: A Case Study of Cobalt. ACS Catal. 2017, 7, 3654-3661. [CrossRef]

106. Matsuishi, S.; Toda, Y.; Miyakawa, M.; Hayashi, K.; Kamiya, T.; Hirano, M.; Tanaka, I.; Hosono, H. High-Density Electron Anions in a Nanoporous Single Crystal: [Ca24A128O64]4+(4e-). Science 2003, 301, 626-629. [CrossRef]

107. McEnaney, J.M.; Singh, A.R.; Schwalbe, J.A.; Kibsgaard, J.; Lin, J.C.; Cargnello, M.; Jaramillo, T.F.; Nørskov, J.K. Ammonia synthesis from $\mathrm{N}_{2}$ and $\mathrm{H}_{2} \mathrm{O}$ using a lithium cycling electrification strategy at atmospheric pressure. Energy Environ. Sci. 2017, 10, 1621-1630. [CrossRef]

108. Jiao, F.; Xu, B. Electrochemical Ammonia Synthesis and Ammonia Fuel Cells. Adv. Mater. 2018, 31, 1-5. [CrossRef]

109. Smith, R.R.; Killelea, D.R.; DelSesto, D.F.; Utz, A.L. Preference for Vibrational over Translational Energy in a Gas-Surface Reaction. Science 2004, 304, 992-995. [CrossRef] [PubMed]

110. Holmblad, P.M.; Wambach, J.; Chorkendorff, I. Molecular beam study of dissociative sticking of methane on Ni(100). J. Chem. Phys. 1995, 102, 8255-8263. [CrossRef]

111. Patil, B.S.; Hessel, V.; Seefeldt, L.C.; Dean, D.R.; Hoffman, B.M.; Cook, B.J.; Murray, L.J. Nitrogen Fixation. In Ullmann's Encyclopedia of Industrial Chemistry; Wiley: Hoboken, NJ, USA, 2017; pp. 1-21. [CrossRef]

112. Patil, B.S.; Wang, Q.; Hessel, V.; Lang, J. Plasma N2-fixation: 1900-2014. Catal. Today 2015, 256, 49-66. [CrossRef]

(C) 2020 by the authors. Licensee MDPI, Basel, Switzerland. This article is an open access article distributed under the terms and conditions of the Creative Commons Attribution (CC BY) license (http://creativecommons.org/licenses/by/4.0/). 